\title{
Uma trajetória do Arquivo Fotográfico do Iphan: mudanças discursivas entre os anos 1970 e 1980
}

\section{Eduardo Augusto Costa ${ }^{1}$}

RESUMO: Este trabalho aborda questões relacionadas à representação imagética no Instituto do Patrimônio Histórico e Artístico Nacional (lphan), especialmente entre as décadas de 1970 e 1980. Apresenta aspectos das mudanças profundas ocorridas no contexto político cultural brasileiro e também nos debates patrimoniais de âmbito internacional, na época, com fundamental atuação por parte da visualidade arquivada nesse instituto. Para tanto, centra-se a reflexão sobre o Arquivo Fotográfico do Iphan, como instituição chave na organização e na cristalização das ideias e narrativas quanto ao patrimônio. Não apenas o referencialmente em trabalhos realizados nas primeiras décadas de funcionamento desse instituto, mas a instauração de uma política editorial ao longo dos anos 1970 e 1980, as mudanças na organização institucional do lphan na política cultural do país e a participação de fotógrafos na virada para a década de 1980 são apresentados como evidências notáveis da transformação posta em marcha a partir dos anos 1970. Finalmente, evidencia-se a preeminência do Arquivo Fotográfico no reconhecimento da própria trajetória do Iphan. PALAVRAS-CHAVE: Arquivo. Cultura Visual. Patrimônio. Iphan.

ABSTRACT: This paper addresses the issue of image representation in the National Historic and Artistic Heritage Institute, Iphan, between the 1970s and 1980s. With deep changes in the Brazilian political and cultural context and also in the international heritage debates, it's about to present certain aspects of these changing scenario, with an important performance played by the archived visuality by this Institute. Therefore, the Iphan's Photo Archive is presented as key element, a major institution in the organization and consolidation of ideas and narratives. Thus, this paper refers not only to the works done in the first decades but the establishment of an editorial policy over the years 1970 and 1980, changes in the institutional organization of Iphan and in the Brazil's cultural policy and, finally, in the activity of photographers at the turn to the 1980s, presenting then as evidence of the remarkable transformation initiated at the beginning of the 1970s. Finally, it is about to put in evidence the preeminence of the Photo Archive as a major institution in the recognition of the Iphan's trajectory. KEYWORDS: Archives. Visual Culture. Heritage. Iphan.
1. Pós-Doutorando no Departamento de História, do Instituto de Filosofia e Ciências Humanas da Universidade Estadual de Campinas (IFCH/Unicamp). BOlsista PNPD/CAPES. E-mail: <eduardocosta01@ gmail.com> 
2. Para facilitar a leitura, utilizarei sempre a designação Iphan, por ser a utilizada em tempo presente. As outras designações serão utilizadas quando se tratar de citação ou forem fundamentais para o entendimento de fatos específicos. Da mesma maneira, utilizarei superintendência, para os núcleos regionais.

3. Em oposição a um discurso construído como cristalino pelo próprio Iphan (ver Rodrigo Melo Franco de Andrade [1986,1987], dentre outros) vale destacar, por exemplo, o trabalho de Baumgarten e Tavares, sobre a historiadora Hanna Levy. Ver Jens Baumgarten e André Tavares (2014).

4. Refiro-me ao Arquivo Fotográfico da Diretoria do Iphan. É certo, no entanto, que as características latentes a esse arquivo se referem também aos outros arquivos fotográficos organizados pelas superintendências do Iphan, nos diversos estados da Federação.

5. Ver Mário de Andrade (1981).

6. Destaca-se a Portaria $n^{\circ} 3$, de 8 de janeiro de 1948 , intitulada "Fotografias de Obras de Valor Artístico e Histórico", na qual se debatiam "instruções a serem observadas pelos técnicos e auxiliares incumbidos de colher fotografias de monumentos e obras de arquitetura, pintura, escultura e arte aplicada...". No entanto, vale destacar que esses instrumentos, apesar de buscarem padrões e estabilidades ao serviço, não restringiram certas heterogeneidades ao conjunto, o que, em certa medida, muito caracteriza esse arquivo. Ver Eduardo Augusto Costa(2015).
A história do patrimônio no Brasil revela-se através de sobreposições coladas à própria história do Instituto do Patrimônio Histórico e Artístico Nacional, - Iphan². Foi especialmente por meio das publicações, pareceres, declarações, restauros, intervenções e tantas outras ações realizadas por esse instituto, que historiadores, sociólogos, antropólogos, arquitetos e outros profissionais puderam colocar em prática projetos intelectuais. Projetos que, se apresentados como homogêneos e regulares, como que totalizantes, vêm sendo revelados, por recentes pesquisas ${ }^{3}$, como corpos complexos, ambíguos e irregulares, o que bem pode ser acompanhado por meio dos documentos pertencentes também a esse instituto. Uma análise da longa trajetória do Iphan permite revelar particularidades que perduraram no decorrer do tempo, mas que também passaram por revisões ou reavaliações, definindo, assim, novos rumos para o pensamento e a produção de patrimônios. Nesse sentido, o Arquivo Fotográfico do Iphan ${ }^{4}$ ganha destaque não apenas por acompanhar a trajetória da instituição a que pertence, mas, em especial, por ser ele um dos principais instrumentos de persuasão, na busca pela estabilidade dos sentidos e significados, assim como para a transformação de diretrizes.

É preciso destacar que a importância do Arquivo Fotográfico pode ser acompanhada desde a criação do Iphan. Mesmo antes da promulgação do Decreto Lei n 25 , a fotografia foi alvo de reflexão por parte de seus diretores e superintendentes. Dinâmicas de definição, produção, circulação e arquivamento foram temas de longos debates, por exemplo, entre Rodrigo Melo Franco de Andrade e Mário de Andrades, revelando a importância de se organizar um material condizente com as diretrizes desses serviço. Não só os decretos-lei, que definiram os instrumentos legais de atuação do instituto em sua trajetória, mas também as portarias serviram para a organização de um quadro mais homogêneo do que se pretendia enquanto visualidade a ser arquivada e, portanto, preservada 6 . Assim, é certo localizar, no regime de realização, organização e divulgação da interioridade desse arquivo, o meio pelo qual o Iphan instituiu balizas para o processo de cristalização de certas ideias, além de ações futuras e concretas a serem postas em prática, principalmente, por arquitetos e historiadores no interior desse instituto, mas também por uma comunidade de críticos e especialistas em seu exterior. Pode-se dizer, portanto, que a feitura do Arquivo Fotográfico se refere à própria organização de um futuro para a história do patrimônio no Brasil 7 . Futuro que aqui é entendido por meio da definição de arquivo, já que por ser uma promessa de futuro tem uma responsabilidade com um amanhã, como apontado por Jaques Derrida, Michael Foucault ou Paul Ricoeur, que aqui organizam os conceitos em relação a esse tema ${ }^{8}$. Essa responsabilidade com o amanhã refere-se justamente, ou ao menos incide potencialmente, sobre o que o Iphan disponibiliza em tempo presente, como referencial oficial passível de ser consultado, como lugar e matéria com a qual se pode trabalhar hoje a respeito do patrimônio brasileiro. Mesmo que em sua tessitura seja possível encontrar certos ruídos frente a uma pretensa representação homogênea, o que o instituto disponibiliza hoje com seu arquivo refere-se, em grande medida, a um projeto ou aos projetos pensados para 
o seu futuro, o que se desdobra nas próprias concepções de patrimônios. Trata-se, ainda, de pensar a história do patrimônio na relação com a Cultura Visual?, especialmente nos jogos de poder associados ao controle dos discursos visuais.

Nesse sentido, vale destacar que os fotógrafos, operadores ou peritos em belas artes - como muitas vezes foram designados os responsáveis pela realização de documentos fotográficos - compõem, para além dos anônimos, um conjunto extenso com mais de 350 nomes. Trata-se, portanto, de um extenso Arquivo Fotográfico, composto por diversos suportes e formatos, que encontra um objetivo comum na medida em que os discursos são organizados por meio do diálogo com os fotógrafos, bem como na escolha daquilo que pode ou não ser apresentado, visualmente, em relação aos bens inventariados. É, portanto, natural identificar, no discurso dos próprios servidores do lphan, um conjunto de fotógrafos no qual se identificou, ou ao qual se atribuiu, a responsabilidade pela feitura da Documentação Oficial10. Documentação que é a mais importante do arquivo, por se tratar da que preserva a imagem acabada do bem, aquela que incide sobre a própria materialidade do bem. A identificação desse aspecto que recai sobre a documentação arquivada é fundamental para a compreensão das próprias mudanças de projetos intelectuais que balizaram e organizaram as ações realizadas pelo instituto. É, portanto, nessa documentação que se pode reconhecer permanências, como também mudanças de linhas de pensamento corroboradas pelos servidores do Iphan, pelas próprias organização e tessitura dos documentos desse arquivo fotográfico. É nesse sentido que se pode identificar, entre as décadas de 1970 e 1980, mudanças estruturais na visualidade arquivada, que estão, intimamente, associadas a iniciativas como o Programa Integrado de Reconstrução das Cidades Históricas - PCH, criado no ano de 1973.

Uma importante evidência da mudança que ocorrera nesse período vêse em um prefácio de uma publicação em homenagem ao falecido diretor do Iphan, Rodrigo Melo Franco de Andrade, no qual o Chefe da Divisão de Estudos e Tombamentos, Lúcio Costa, relaciona fotógrafos que teriam contribuído com o Iphan. Segundo ele:

Foram vários os fotógrafos que serviram ao Sphan: o notável lituano Vosylius, Pinheiro, Benício Dias, Marcel Gautherot, o mais artista, que certa manhã irrompeu repartição a dentro sobraçando uma pasta com belas fotos da Acrópole, na companhia de Pierre Verger, que o visgo da Bahia iria pegar para sempre, e o simpático Erich Hess, disposto a voar fosse para onde fosse ${ }^{11}$.

Em outro trecho, em que discorre sobre as atividades da Superintendência de São Paulo, destacando o trabalho pormenorizado de Luis Saia e o de Antônio Luiz Dias de Andrade, o arquiteto não deixa de notar a assistência dada pelo "veterano Hermann (sic) Graeser, excelente fotógrafo"12. Nesse prefácio publicado em 1986, o Chefe da Divisão de Estudos e Tombamentos destaca, portanto, não apenas certos aspectos do cotidiano do Iphan, contribuindo com uma narrativa acerca de Rodrigo Melo Franco de Andrade, mas parece tratar-se, ainda, de uma
7. Essa visibilidade, ao ser organizada no interior do governo federal, acaba por ser determinante no que veio a se estabelecer em outras instituições ligadas ao patrimônio, em níveis estadual e municipal. Por isso, torna esse evento ainda mais significante para o entendimento da história do patrimônio.

8. Ver Jaques Derrida (1995); Michel Foucault (2009); Paul Ricoeur (2007).

9. Vale aqui destacar que este artigo está balizado pela noção de Cultura Visual já muito debatida em trabalhos como os elaborados por Svtlana Alpers (1999) e Michael Baxandall (1971, 1991), assim como os de Paulo Knauss (2006) e o importante ensaio de Ulpiano Bezerra de Meneses (2003). Neste último caso, vale destacar a identificação de questões relacionadas à visão, ao visível e ao visual, que permeiam questões ligadas aos sistemas de comunicação visual, produção, circulação, consumo, os sistemas de controle e ao poder das imagens, que aqui aparecem assinaladas ao longo do texto.

10. Eduardo Augusto Costa (2015).

11. Cf. Lúcio Costa (1986, p.9).

12. Ibidem. 
13. Entrevista concedida ao autor em 15 de outubro de 2013.

14. Ver Silvana Rubino (1991).

15. Fotos 21872 a 21883 do Livro de Registro de Fotografias, Arquivo Central do Iphan. Para além das 12 fotografias realizadas por Gautherot, importa notar que o Arquivo Fotográfico guarda um conjunto de cerca de 90 fotografias do processo de restauro, dentre as quais 16 foram também realizadas após o restauro, como as fotos de Gautherot. Todas essas outras fotografias, no entanto, não têm autoria creditada.

16. Quanto à relação de Gautherot com os arquitetos modernos, ver: Heliana Angotti-Salgueiro (2014); Heloisa Espada (2014).

17. Pode-se dizer que essa tenha sido uma das características mais distintas do patrimônio visual arquivado pelo Iphan, que também guarda um grande conjunto de documentos em formatos menores. Vale, ainda, a indicação de que o serviço realizado por Gautherot não se restringiu a um único formato documental, mas teve sim contribuições nos três formatos: grande formato, médio formato e $35 \mathrm{~mm}$. importante fala, que irá contribuir com a consolidação de uma memória para o instituto, reservando atenção também à visualidade. Memória que se refere às primeiras décadas de seu funcionamento e não às ações levadas a cabo em tempo presente. Nesse sentido, vale destacar algumas breves características da atuação desses fotógrafos, o que bem informa sobre o sentido atribuído à narrativa.

No que se refere à obra de Kasys Vosylius, a outorga refere-se a uma demanda técnica e a uma necessidade de se atribuir valor documental ou, ainda, precisão científica ao Arquivo Fotográfico do lphan. Segundo a museóloga Lygia Martins Costa, responsável pelos pareceres técnicos de obras de arte nesse instituto, "Como fotografia de estudo, não há ninguém que tenha feito como ele. Ele era o melhor! Absolutamente nítido! A gente via tudo! É, de longe, o melhor fotógrafo!" 13 . Trata-se, nesse caso, da nitidez e, por consequência, da qualidade pictórica dos registros, dos protocolos inerentes a essa documentação - questão que parece fundamental para a compreensão da atribuição indicada por Lúcio Costa. Quanto a Silvanísio Pinheiro e Benício Whatley Dias, a indicação do trabalho desses fotógrafos refere-se mais à relação que tiveram, respectivamente, com a Bahia e com o Recife, onde assumiram a responsabilidade pela grande maioria dos documentos produzidos em dois dos estados de maior representação no que se refere aos tombamentos e restauros executados pelo Iphan nas primeiras três décadas, como já apresentado por Rubino ${ }^{14}$. Benício Dias foi também um importante interlocutor de Gilberto Freyre e Robert Chester Smith, intelectuais de especial importância na trajetória do Iphan, garantindo-lhe menção por parte de Lúcio Costa, o que, num certo sentido, revela mais da intenção de marcar a abrangência de atuação do instituto do que da atribuição de valor à obra do fotógrafo.

A menção ao trabalho de Marcel Gautherot refere-se não apenas aos importantes trabalhos por ele realizados, como a documentação da lgreja de São Miguel das Missões, após o restauro realizado pelo Iphan ${ }^{15}$, ou mesmo a documentação dos Profetas e dos passos de Aleijadinho, na cidade de Congonhas do Campo em Minas Gerais. Marcel Gautherot era também um dos fotógrafos preferidos dos arquitetos modernos ${ }^{16}$ que foram formados pelo então professor Lúcio Costa, colocando-o entre a produção de uma imagem para o patrimônio e a de uma vanguarda da arquitetura brasileira. Reafirmava-se, assim, a própria chave narrativa dessa geração - antigo-novo, tradição-modernidade - organizada por meio de uma estética mais próxima a uma linguagem moderna, própria de câmeras mais leves e formatos menores ${ }^{17}$. Nesse mesmo sentido, a menção a Pierre Verger, que teve contribuições muito pontuais para o Arquivo Fotográfico do lphan, parece ganhar sentido, já que o fotógrafo francês habitava o imaginário brasileiro e contribuía de maneira singular para a organização de uma cultura fotográfica e, assim, contribuía com a atribuição de significado, validando a visualidade arquivada pelo instituto. Tratava-se, nesse caso, de uma ação que, se por um lado reconhecia a visualidade do lphan frente a um contexto contemporâneo dos anos 1980, muito ligado a uma ideia de fotografia autoral, por outro acabou por minimizar a própria característica científica intrínseca a esse serviço. 
A natureza do Arquivo Fotográfico do Iphan parece ganhar outros significados com o destaque dado também à contribuição de Erich Hess, fotógrafo amador, que iniciou suas atividades no Rio de Janeiro, no ano de 1936. Nesse caso, a referência encontra-se associada muito mais a um trabalho de cotidiano da burocracia do Iphan, em que os servidores do órgão puderam melhor intervir na própria produção do fotógrafo, já que essa inexperiência era também meio pelo qual foi possível aplicar um maior controle à documentação. Não por menos, Lúcio Costa executava croquis ao fotógrafo, indicando as fotografias que deveriam ser feitas ${ }^{18}$. Por outro lado, Herman Hugo Graeser, experiente fotógrafo de estúdio, garantia a qualidade pretendida ao Arquivo Fotográfico, realizando documentos protocolares compatíveis com os objetivos desse serviço. Não por menos, os documentos produzidos por ele são, ainda hoje, os mais consultados e aqueles que servem de referência enquanto feição original a ser preservada pelo Iphan. Mas é certo que a menção ao trabalho de Graeser se deu, bem como a indicação ao trabalho de Erich Hess, por exemplo, pela importância assumida por essa documentação da diretoria do Iphan, a partir da qual se pode identificar, pela rotina dos serviços prestados, uma atribuição de valor a uma certa trajetória deste Instituto. Essa ação é encampada pelo Chefe da Divisão de Estudos e Tombamentos e se apresenta enquanto evidência das mudanças institucionais, num momento em que as açõesdo PCH já haviam contribuído com transformações no interior do lphan.

Se o trabalho de Herman Hugo Graeser pode ser compreendido como atividade intrínseca ao cotidiano das atividades do Iphan e, portanto, muito associado a um trabalho de peritagem, é sensível que o Museu Lasar Segall, ainda enquanto associação civil e antes de ser incorporado ao instituto, tenha realizado, no ano de 1981, uma exposição dedicada ao trabalho desse fotógrafo. Com o tema "Fotografia e Documentação", o catálogo resultante da exposição detalha a trajetória do fotógrafo, especificando não só seu cotidiano no lphan, mas também os serviços prestados na cidade de São Carlos. Para além dos textos do historiador, Jaelson Bitran Trindade, e do Superintendente do Iphan em São Paulo, Antônio Luiz Dias de Andrade, Maurício Segall explica as intenções da mostra, que viria a fomentar os debates já iniciados no departamento fotográfico do museu sob sua direção. Tratava-se de incentivar a reflexão da arte fotográfica, "num momento em que tanto se fala de criatividade e documentação e que também a arte fotográfica começa a ser divulgada com respeito e admiração"19. A fala de Segall é precisa para o reconhecimento de que, ao contrário da atribuição indicada pelo lphan, ao longo de suas primeiras décadas de funcionamento, a fotografia de Herman Hugo Graeser representaria uma arte fotográfica e não mais um serviço de peritagem, mesmo que ainda ligado a uma ideia de documentação. Essa sensível distinção parece também contribuir para o entendimento e o reconhecimento da obra de Herman Hugo Graeser por parte de Lúcio Costa, cinco anos depois da mostra dedicada ao fotógrafo.

Em oposição a uma perspectiva do trabalho de Herman Hugo Graeser enquanto atividade técnica e, no limite, científica, o que seria natural para um
18. Ver Erich Hess, s/d.

19. Ver Maurício Segall (1981, p.7) 
20. Apesar de contribuições isoladas ao longo do século $\mathrm{XX}$, como o artigo de Gilberto Ferrez para a Revista do Patrimônio Histórico e Artístico Nacional, em 1953, é apenas nos anos 1970 que se inicia um conjunto de iniciativas em busca de uma efetiva organização de uma história para a fotografia brasileira. Para tanto, ver: Boris Kossoy (1976).

21. Esse número leva em conta apenas as ampliações fotográficas, excluindo os negativos.

22. Ver Nestor Garcia Canclini (2008, p. 190-193). servidor do instituto, o reconhecimento do trabalho desse fotógrafo na mostra do Museu Lasar Segall se deu, em grande parte, pela via artística, a do fotógrafo autor. Nesse contexto, importa realçar que, nos Livros de Registros de Fotografia do Iphan, a referência indicada foi feita enquanto "operadores" e não "fotógrafos". Designação de pequena alteração, mas de grande significado para o entendimento da fala de Lúcio Costa, no ano de 1986, no que se refere a uma precisa seleção de sete fotógrafos dentre tantos outros nomes. $\bigcirc$ que se coloca em evidência com a mostra realizada para Graeser, tomado por Maurício Segall como um artista, refere-se justamente a uma profunda transformação no estatuto da fotografia no Brasil, incluindo-se aí o interior do Iphan. Se antes uma atividade técnica realizada segundo balizas e protocolos, naquele momento, indicava-se que a documentação produzida por alguns dos fotógrafos e ali arquivada seria eminentemente arte e não mais documento científico. A exposição "Fotografia e Documentação" funciona, portanto, como uma evidência de uma transformação posta em marcha.

O longevo projeto, iniciado nos anos 1930, passa, entre os anos 1970 e 1980, por uma significativa transformação, projetando outros caminhos para o reconhecimento da fotografia, do Arquivo Fotográfico e do próprio Iphan. A perspicaz indicação desses sete fotógrafos por parte do Chefe da Divisão de Estudos e Tombamentos do Iphan revela, ainda, um contexto por meio do qual se pode notar uma profunda mudança na cultura brasileira, que teria grandes desdobramentos para a organização da visualidade do país e, por fim, para a própria história da fotografia, ainda prematura no Brasi ${ }^{20}$. A esse instituto, por consequência, estariam reservadas mudanças que se iniciaram nos anos 1970, com significativa importância nas ações do $\mathrm{PCH}$, e que, por certo, tiveram consequências relevantes no que se refere a uma memória arquivada da visualidade do patrimônio brasileiro, uma memória projetada para o futuro. Identificar essas mudanças parece, portanto, fundamental para o entendimento e o reconhecimento de uma memória latente, ainda hoje no Iphan, e muito associada à visualidade do patrimônio brasileiro.

O contexto de transformação cultural do Brasil pode ser acompanhado por meio do próprio Arquivo Fotográfico do Iphan. $\bigcirc$ volume de documentos fotográficos associado pelo instituto cai sensivelmente ao que vinha sendo praticado anteriormente. Das 1700 fotografias $^{21}$ incorporadas anualmente, passa-se a integrar, em média, conjuntos menores que 500. No ano em que o Al-5 foi instaurado, 1968, esse número cai para 262 fotografias e, entre 1970 e 1973, não ultrapassa os 806 documentos incorporados anualmente. É, portanto, notável que, na década de 1970, tenha-se produzido pouco, no que se refere à formação de seus arquivos, especialmente dedicados à cultura brasileira. Característica muito distinta adas primeiras décadas de funcionamento do instituto. Assim, a contínua e necessária solidariedade afetiva, os ritos, que encontram lugar nas comemorações, nos museus e monumentos, mesmo que ainda numa chave tradicionalista, como destacado por Canclini22, perdem lugar nesses momentos. Aqui, em especial, é o arquivo que sofre com a condição política do Estado, pouco interessado em 
promover a cultura no país. Cria-se, portanto, uma cisão e uma desarticulação que tendem a minar o reconhecimento da população para com aquilo que faria identificá-la enquanto unidade. $\bigcirc$ Patrimônio parece, portanto, não ter lugar nesse cenário antidemocrático. Por outro lado, a Ditadura Militar dedicou sua ação também a um imaginário visual, mas, nesse caso, deixando de investir em representações ligadas ao passado.

Ao longo dos anos 1970, passou-se a dar ensejo à construção de uma representação visual desenvolvimentista e de grande intervenção no território ainda não colonizado pela elite do país. Revistas, jornais, televisões e outros meios de comunicação, regulados pelo Estado, contribuíram com a formação desse imaginário, em que a ocupação do território estabelecia um novo paradigma de país, uma "marcha para o oeste" brasileiro, destinada a ocupar em especial o território amazônico e o Centro-Oeste brasileiro. Essa relação o historiador Adrián Gorelik já assinalou para o caso da construção de Brasília, na organização de um papel simbólico de "unificação de litoral e sertão" 23 e, por fim, favorecimento da ocupação do território nacional, nas décadas seguintes. Passou-se, assim, a compor - imaginário da ocupação desse território com novas fronteiras agrícolas, implementação de complexos industriais, novas hidrelétricas e rodovias, o que pode ser acompanhado em revistas como $\bigcirc$ Cruzeiro (1928-1975) e, especialmente, pela revista Manchete (1952-2000), que tiveram seus fotógrafos em um papel determinante ${ }^{24}$. Nesse contexto, a representação ou mesmo o espaço dedicado ao patrimônio histórico é reduzido de maneira sensível, e o lphan tem seus investimentos e participação diminuídos no imaginário cultural do país.

Um exemplo dessa mudança de lugar do Iphan pode ser acompanhado na própria trajetória da Revista do Patrimônio. Ao longo da década de 1960, são lançados apenas três números da revista, sendo um primeiro em 1961, ainda no período de direção de Rodrigo Melo Franco de Andrade, e os outros dois números nos anos de 1968 e 1969, logo após o falecimento do diretor. A década de 1970, por outro lado, a revista teve apenas um número editado, publicado em 1978, quando o então diretor, Renato de Azevedo Duarte Soeiro, como se estivesse comemorando uma espécie de retomada da revista, ressaltou a importância da publicação, elaborada como meio de difusão e semeada para o futuro da cultura nacional. São, portanto, apenas quatro números da revista publicados ao longo de duas décadas, nos quais o tom de memória parece encarnado não apenas na lembrança de Rodrigo Melo Franco de Andrade, com a retomada de um de seus discursos ${ }^{25}$, mas também na manutenção de temas consagrados pelo Iphan, como o Patrimônio Mineiro, a obra de Aleijadinho, a iconografia das cidades e dos monumentos, dentre outros assuntos. Nessas publicações, perduram não apenas os temas aclamados pelas primeiras gerações do Iphan, mas também os autores ${ }^{26}$ e a própria estrutura editorial dos anos 1930, mantida pela comissão responsável da publicação.

No momento em que o país parece deslocar sua narrativa para o desenvolvimentismo, é sensível que a revista do Iphan tenha tido tão pouco
23. Cf. Adrián Gorelik (2005).

24. Helouise Costa (2012); FLIEG (2014).

25. Ver Rodrigo Melo Franco de Andrade (1978, p.11-74).

26. Dentre os autores, podese citar Robert C. Smith, Lúcio Costa, Lygia Martins Costa, Judith Martins e outros, que mantiveram contribuições constantes no decorrer da trajetória dessa revista. 
27. Vale alertar que esse ímpeto pela organização de uma memória da instituição não ocorre apenas como resposta a uma falta de interesse e investimento por parte do Estado, mas também por conta de mudanças estruturais no interior do Iphan.

28. Nesse caso, pode-se destacar: Augusto Carlos da Silva Telles (1980). Publicado em 1975, atendia às requisições do Compromisso de Brasília, como livro didático destinado ao ensino médio e superior. Ver Isabelle Cury (2003). Vale ainda destacar, no caso da preservação dos documentos, ações como a de Edson Motta, que, desde 1944, respondia pelo Setor de Recuperação de Obras de Arte do Iphan. Em 1971, Motta, em parceria com Maria Luiza Guimarães Salgado, publicou uma obra, ainda hoje, de referência sobre a conservação de papel, o que teve impacto significativo sobre a preservação da própria documentação do Iphan. Ver Edson Motta; Maria Luiza Guimarães Salgado (1971).

29. Ver Mário de Andrade (1981).

30. Um dos elementos que indicam a estabilidade dessa referência a Rodrigo Melo Franco de Andrade é a publicação, em 1969, de um livro em memória à trajetória do diretor. Ver Rodrigo Melo Franco de Andrade (1986). investimento ou atenção por parte do Estado e que, quando publicada, as narrativas consagradas tenham perdurado, como que cultivando uma memória ou, talvez, buscando manter um estatuto organizado no tempo passado. Nesse sentido, se ao Estado não interessava investir no passado, como se pode atestar pela trajetória do Arquivo Fotográfico, uma das alternativas ao Iphan parece ter sido a elaboração da memória de sua própria trajetória, especialmente entre as décadas de 1960 e 198027. A formação de uma memória do instituto ganha força nesse contexto, culminando em dezenas de ações que partem não apenas de políticas de tombamento, mas também de políticas de preservação de documentos da instituição, além de um conjunto de publicações dedicadas às suas primeiras décadas, reiterando a exemplaridade de certos monumentos consagrados ${ }^{28}$. Ainda no que se refere à consolidação da memória do Iphan, pode-se destacar um investimento na política editorial, com a publicação de três livros que foram importantes para a estabilidade dessa memória da trajetória da instituição e que, até hoje, representam referências importantes para a história do patrimônio no Brasil.

Uma política editorial no Iphan

Publicado no ano de 1981, o livro Mário de Andrade: Cartas de Trabalho ${ }^{29}$ funciona como uma das peças que dão estabilidade a uma narrativa centrada no autor do Anteprojeto do o Serviço do Patrimônio Artístico Nacional (SPAN), ainda sem o " $\mathrm{H}^{\prime}$ de história em sua legenda. Dedicado à figura desse autor paulista, tratava-se de ressignificar a origem da história do patrimônio, uma vez que a esse anteprojeto, elaborado em 1936, é atribuída uma origem do debate do Patrimônio Cultural desse instituto - outorga aferida pela própria diretoria do Iphan, no final dos anos 1970. A publicação não apenas traz o referido documento, organizando uma origem, uma memória para o patrimônio, mas também cartas, ofícios e relatórios produzidos por Mário de Andrade. Nesse sentido, nota-se que o lugar atribuído a Mário de Andrade, no processo de conformação da narrativa, parece assegurado e validado por meio da relação que se estabelece entre ele e Rodrigo Melo Franco de Andrade. Para tanto, as cartas selecionadas e reunidas nessa publicação foram justamente aquelas trocadas com o antigo diretor, assim como os relatórios e ofícios estão diretamente vinculados a Rodrigo Melo Franco de Andrade. Essa associação parece engenhosa e especialmente importante, pois, enquanto diretor do Iphan, ao longo das três primeiras décadas de funcionamento desse instituto, tem sua memória, em grande medida, já estável e incorporada à narrativa da memória da instituição ${ }^{30}$. Por outro lado, Mário de Andrade, falecido em 1945, parece que não lograva de tal notoriedade ao fim do período de direção de Rodrigo Melo Franco de Andrade, fazendo com que sua ligação seja reatada justamente por aquilo que the difere da narrativa oficial estabelecida, até então, pelo Iphan. É, portanto, pelo Patrimônio Cultural e não apenas pelo patrimônio de "pedra e cal" que Mário de Andrade 
encontra lugar de destaque nessa trajetória. É pela arte popular e pela etnografia, em ascensão a partir do final dos anos 1970, que se estabiliza, de uma vez por todas, a singularidade do papel de Mário de Andrade no processo de conformação de uma história para o patrimônio brasileiro. Nota-se, portanto, que a articulação entre Mário de Andrade e Rodrigo Melo Franco de Andrade e uma memória da instituição que perpassa a trajetória dos dois servidores se dá não apenas pelos documentos textuais, mas, em especial, por meio do reenquadramento de uma fotografia na qual ambos aparecem lado a lado ${ }^{31}$. Nesse caso (Figura 1), os dois pintores, Antônio Bento e Cândido Portinari, são retirados do quadro, fazendo com que a narrativa visual da fotografia seja reduzida ao que interessa à narrativa: a vinculação de Mário de Andrade e Rodrigo Melo Franco de Andrade. Ainda em relação a essa publicação, deve-se destacar o pequeno conjunto de fotografias utilizado para ilustrá-la.

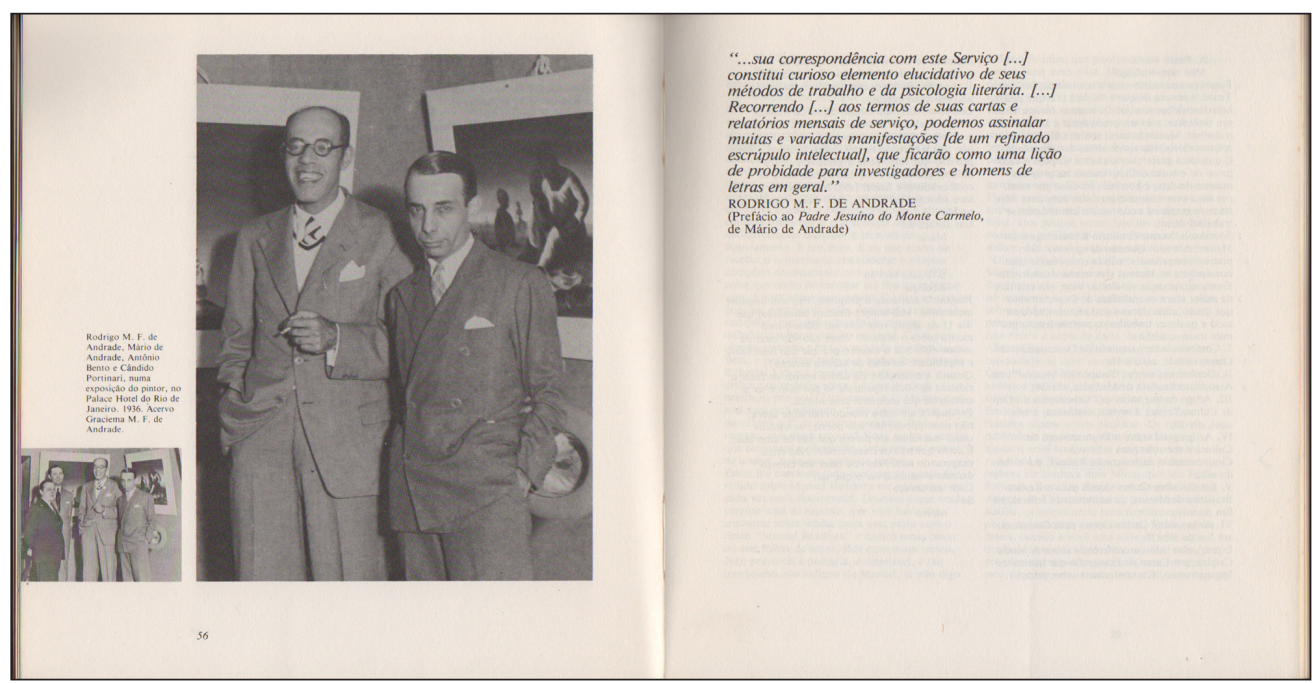

Figura 1 - Rodrigo M. F. de Andrade, Mário de Andrade, Antônio Bento e Cândido Portinari, numa exposição do pintor (Candido Portinari), no Palace Hotel do Rio de Janeiro, 1936. Acervo Graciema M. F. de Andrade 32.

Relacionados lado a lado aos temas abordados, os documentos são articulados de maneira a fazer sentido ao conjunto ou ao texto apresentado. Em muitos casos, no entanto, as fotografias destacadas não correspondem exatamente aos documentos relacionados pelo texto, como se pode notar com a inclusão de documentos fotográficos da década de 1940 ao Primeiro Relatório, elaborado por Mário de Andrade, em 16 de outubro de 1937. A publicação do lphan parece, portanto, ter elaborado um processo de reedição do documento, prezando por fotografias melhor concebidas, canonizando, assim, não apenas a importante participação de Mário de Andrade para a memória do instituto, mas, também, a própria visualidade da Superintendência do Iphan em São Paulo. Vale ainda lembrar que essa publicação foi realizada no mesmo ano em que foi montada a exposição Fotografia e Documentação, com trabalhos de Herman Hugo Graeser,
31. Destaca-se a seguinte passagem: “... sua correspondência com este Serviço (...) constitui curioso elemento elucidativo de seus métodos de trabalho e da psicologia literária (...) Recorrendo (...) aos termos de suas cartas e relatórios mensais de serviço, podemos assinalar muitas e variadas manifestações [de um refinado escrúpulo intelectual], que ficarão como uma lição de probidade para investigadores e homens de letras em geral". Cf. Mário de Andrade (1981, 56-57)

32. Cf. Mário de Andrade (1981, 56-57) 
33. Cf. Rodrigo Melo Franco de Andrade (1986).

34. Idem, p.9

35. Ibidem.

36. Cf. Rodrigo Melo Franco de Andrade (1987, p.5) no Museu Lasar Segall. Assim, tanto a exposição de fotografias, organizada por um museu de relevância no cenário cultural paulista e nacional, como a incorporação desses documentos na publicação do Iphan parecem compor uma intenção comum, visando à elaboração de uma memória visual para esse instituto e, nesse caso, para a especificidade de São Paulo, com especial atenção a Mário de Andrade.

Ainda no que se refere à organização de uma memória para o Iphan, entre os anos de 1986 e 1987, publicam-se outros dois livros, recordando a trajetória de Rodrigo Melo Franco de Andrade. $\bigcirc$ tom de homenagem aí ganha maior amplitude por se tratar do período de comemoração dos 50 anos do instituto ou dos "cinquenta anos de Rodrigo", como parece também requerer uma das publicações. Das duas, o livro Rodrigo e seus tempos ${ }^{33}$ merece atenção por ter tido um claro intuito de organizar uma memória do Iphan além da de seu primeiro diretor. Nele, reúnem-se textos de Rodrigo Melo Franco de Andrade como "escritor, jornalista e pesquisador" a respeito da cultura nacional, debatendo não apenas questões relativas a determinados monumentos históricos, mas também a artistas, pesquisadores e arquitetos brasileiros e estrangeiros. Compõe-se, assim, uma memória específica em relação ao primeiro diretor e aos temas, artistas e pesquisadores dignos de consideração, sem deixar de apontar para um discurso sobre o próprio instituto. Não por menos, o arquiteto Lúcio Costa organiza o prefácio da publicação, que não se refere especificamente à "obra 'ministerial' (...) do Rodrigo" 34 , mas a uma trama de trajetórias enlaçadas às especificidades do serviço. A intenção de Lúcio Costa, segundo o próprio chefe da Divisão de estudos e tombamentos, foi "relacionar e lembrar as pessoas e personalidades que, no SPHAN, com ele conviveram e atuaram, tendo principalmente a sua querida e singular figura encarada de um ponto de vista eminentemente pessoal". Foi assim que acabou por recorrer a mais de uma dezena de contribuições, sem deixar de atentar aos "fotógrafos que serviram ao SPHAN"35. Desse modo, o arquiteto, no papel de representante do instituto, talvez aquele que mais autorizado pelo seu papel desempenhado junto a Rodrigo Melo Franco de Andrade, organiza uma narrativa em que o tom personalista e autoral ganha força, localizando no diretor do Iphan a centralidade de uma memória em vias de ser cristalizada.

Uma última publicação parece mais diretamente relacionada à trajetória do Iphan, já que, nesse caso, tratam-se dos textos, entrevistas e discursos elaborados por Rodrigo Melo Franco de Andrade e especialmente ligados à rotina do serviço. Em Rodrigo e o SPHAN, o jurista Marcos Vinícios Rodrigues Vilaça, então diretor do Iphan, destaca a trajetória do "Patrimônio", compreendido como "O Patrimônio Histórico de Capanema, de Mário, de Afonso Arinos, de Drummond, de Lúcio, de Godofredo, de Saia, de Aírton, de Soeiro, de Ferrão, de Oscar, de Silva Teles e de tantos outros ao longo destes anos. Mas, principalmente, o 'Patrimônio' de Rodrigo." ${ }^{36}$. É sensível que, nesse livro de 1987, a trajetória do Iphan seja como que sobreposta pela atuação desses servidores, em especial a de Rodrigo Melo Franco de Andrade, atribuindo autoria e personificando a história desse serviço público. É certo que a trajetória do instituto não pode ser desvinculada da íntima 
relação com o percurso de cada um deles, servidores, que dedicaram muitos anos de sua vida a esse serviço ${ }^{37}$. Parece, no entanto, importante notar que essa sobreposição funciona designando autoria às realizações e às atividades organizadas, no momento de comemoração dos cinquenta anos da instituição. Momento em que se consolidava sua memória. Por fim, é notável que essa publicação estipule um paralelo com o livro Mário de Andrade: Cartas de Trabalho ${ }^{38}$, já que trouxe as cartas de resposta àquelas enviadas por Mário de Andrade e publicadas no livro de 1981, consolidando, assim, uma unidade entre os três livros. Esse conjunto pode ser notado na clara proposta editorial coordenada pelo designer João de Souza Leite, responsável, naquele momento, pelo Núcleo de Editoração do Iphan. Como o livro Rodrigo e o SPHAN deixa claro em sua quarta capa, buscava-se:

(...) registrar e divulgar o trabalho desenvolvido (...) As atividades visando a estes fim constituem a série Memória da Instituição, que já resultou nos livros: Mário de Andrade: cartas de trabalho; Rodrigo e seus tempos; Rodrigo e o SPHAN, e na publicação de fascículos, reunidos sob a denominação SPHAN - Memória oral, com depoimentos de antigos funcionários e colaboradores do órgão criado pelo governo federal para dar proteção a seu acervo histórico e artístico ${ }^{39}$.

Tratava-se, portanto, de uma série organizada pelo próprio lphan, com objetivos claros de proteger o seu acervo e, por fim, a sua própria trajetória, para o que, no âmbito da visualidade, a exposição dedicada à obra de Herman Hugo Graeser parece ter funcionado. Optava-se pelo projeto de uma memória a ser cristalizada pela própria narrativa oficial e, portanto, autorizada pelo lphan. Nesse sentido, parece importante sublinhar a série de entrevistas realizadas com antigos servidores, destacada na passagem acima, a fim de estabelecer um referencial, uma memória para o instituto. Esse trabalho pode ser acompanhado, parcialmente, nas obras publicadas recentemente pelo programa Memória do Patrimônio, organizado em 2007, novamente, para comemorar o aniversário do lphan - dessa vez, os 70 anos.

Entre 2009 e 2013, republicaram-se três entrevistas realizadas pelos servidores do Iphan ao longo da década de 1980. Essas entrevistas foram realizadas no âmbito do Projeto Memória Oral SPHAN/Pró-Memória, sob a responsabilidade do Núcleo de Editoração do lphan, que colheu 27 relatos, entre os anos de 1982 e 1987, além de ter indicado outras 78, que não chegaram a ser realizadas ${ }^{40}$. Dessas entrevistas, apenas seis foram publicadas com reduzida tiragem e em fascículos distribuídos internamente nas superintendências, ao longo das décadas de 1980 e 1990. Terezinha Marinho, coordenadora dessa atividade no Iphan, destacou que o objetivo primeiro dessa ação visava à edição de "depoimentos de profissionais de renome, hoje conhecidos muitos deles no exterior, e que aqui falam de trabalhos pioneiros executados para a SPHAN, numa fase histórica da instituição, chamada de heroica por Mário de Andrade"4l. Augusto da Silva Telles*, Carlos Lemos, Cyro Corrêa Lyra, Don Clemente da Silva Nigra,
37. Vale destacar que a referência ao nome de Oscar [Niemeyer] parece adjetivar o discurso, já que esse arquiteto contribuiu pontualmente com o Iphan, projetando o Grande Hotel, em Ouro Preto.

38. Ver Mário de Andrade (1981).

39. Cf. Rodrigo Melo Franco de Andrade (1987).

40. Para uma compreensão mais ajustada da história oral no Brasil e no Iphan, ver: Analucia Thompson; Hilário Pereira Filho (2009).

41. Teresinha Marinho, apud Analucia Thompson (2009. p.12). 
42. Os três nomes assinalados com asterisco referem-se às entrevistas republicadas nos últimos anos pelo Iphan.

43. Ver Analucia Thompson (2009, p.12).

44. Vale destacar que a republicação de três entrevistas, entre 2007 e 2013, também deve ser inserida num momento de comemoração, agora relativo aos 70 anos da instituição.

45. Ver Sergio Miceli, (1987, p.47)
Dora Alcântara, Edgar Jacinto, Erich Joaquim Hess*, Gilberto Velho, Godofredo Filho, Irapoan Cavalcanti Lyra, José de Souza Reis, Judith Martins*, Lia Motta, Lúcio Costa, Lygia Martins Costa, Mauro Bondi, Nestor Goulart Reis Filho, Marcos Vilaça e Paulo Santos são alguns nomes mobilizados para esse projeto, o que fornece um bom panorama da amplitude do programa e da precisão em selecionar servidores ou personalidades que teriam tido papel de grande destaque para a trajetória do Iphan ${ }^{42}$. Nesse sentido, também a fotografia esteve contemplada, com a presença do fotógrafo Erich Hess, citado pelo arquiteto Lúcio Costa, no ano de 1986. Como já destacado por Analucia Thompson ${ }^{43}$,é latente o "caráter memorialista" dessa ação, estabelecendo um discurso positivo e homogêneo da história eleita para ser preservada pelos próprios servidores.

Ao longo da década de 1980 e, especialmente, no momento de comemoração dos 50 anos do instituto, nota-se que se investiu na organização de uma memória dos trabalhos e das iniciativas realizadas ao longo de suas primeiras décadas ${ }^{44}$. Se por um lado os livros publicados e divulgados consolidariam uma narrativa para o Iphan perante o grande público, por outro, esses depoimentos produzidos e distribuídos internamente reorganizavam um lugar para os próprios servidores. Por outro lado, é notável que, justamente quando o Iphan rearranjava e consolidava uma memória de seu passado, Sergio Miceli, em texto publicado na própria Revista do Patrimônio, indicava os perigos dos caminhos que vinham sendo tomados através destas e outras estratégias. Segundo Miceli

(...) em lugar de incorporar as críticas e sugestões já formuladas, a política preservacionista oficial deixa transpirar indícios preocupantes de que o último grito em matéria de preservação será o trabalho de tombar o próprio SPHAN, buscando justificar a manutenção do 'status quo' fazendo alarde dos méritos do acervo já constituído e do trabalho acumulado 45 .

A perspectiva crítica, frente a um trabalho de organização e cristalização de uma memória positiva e heroica para o Iphan, parece, portanto, já posta nos anos 1980. A crítica de Miceli indica que as ações em prol da preservação dessa memória, passando também pela definição de uma memória visual do patrimônio, andavam em sentido oposto a determinadas avaliações e perspectivas patrimoniais, capitaneadas pelas novas gerações de servidores e que se organizavam desde meados dos 1960. Vale, portanto, destacar que a memória do Iphan foi consolidada nos anos 1980, já num momento de abertura política do país, o que parece indicar que foi um programa possível de ser concretizado apenas a partir do final da década de 1970, reforçando o papel reduzido deste Instituto naquele período. O cenário indicado pela crítica de Miceli, em oposição a um contexto próprio ao Iphan, revela questões fundamentais que se referem a uma mudança de perspectiva ou de leitura da cultura brasileira, o que, inevitavelmente, também prescindiu da reorganização de uma visualidade, com distintas consequências para o entendimento do Arquivo Fotográfico. 
No mesmo número da revista do Iphan em que Miceli realiza a crítica ao processo de patrimonialização do próprio Iphan, publica-se um documento de significativo impacto para o processo de transformação do campo da cultura e do patrimônio no Brasil. Um dos primeiros passos de grande relevância frente à transformação das atividades ligadas ao patrimônio no Brasil, a Carta de Veneza ${ }^{46}$ colocou em destaque não apenas a materialidade do bem, enquanto elemento inerente à preservação, mas também a história e o processo a ele inrínsecos. Foi nessa perspectiva que Lia Motta destacou a importância desse documento frente às atividades organizadas no cotidiano do Iphan, cabendo seu uso não só às novas gerações de servidores, mas, também, às consagradas personalidades do período heroico do instituto ${ }^{47}$. A incorporação dos preceitos da carta demonstra uma ação tanto de Rodrigo Melo Franco de Andrade quanto de Renato Soeiro48 com as transformações que se operaram no cotidiano do Iphan ${ }^{49}$. Com destaque, vale sublinhar visitas realizadas, em 1966 e 1967, por Michel Parent, consultor da Unesco, além de outras que se sucederam ao longo dos anos 1960-197050. Incentivadas especialmente por Renato Soeiro, essas visitas de âmbito internacional redesenharam os objetivos e os modos de atuação do Iphan, a partir do final dos anos 1960. Alguns de seus desdobramentos podem ser notados na elaboração de importantes documentos para a cultura e para o patrimônio, como o Compromisso de Brasília, durante o $1^{\circ}$ Encontro dos Governadores de Estado, Secretários Estaduais da Área Cultural, Prefeitos de Municípios Interessados, Presidentes e Representantes de Instituições Culturais ${ }^{51}$, em 1970, por sugestão de Michel Parent $^{52}$. Foi por meio desse documento que, pela primeira vez, no Brasil, uma carta patrimonial dedicou especial atenção à preservação do patrimônio paisagístico e arqueológico, assim como dos acervos documentais e bibliográficos, sinalizando uma mudança estrutural nas políticas de preservação ${ }^{53}$. Outro importante desdobramento foi a incorporação da Convenção do Patrimônio Mundial, Cultural e Natural, de 1972, elaborada pela Unesco, na qual se definiu como patrimônio cultural, não apenas os monumentos, mas também os conjuntos edificados e os locais de interesse conjugados ao homem e à natureza ${ }^{54}$. Deslocava-se, por fim, de uma narrativa até então dominante e associada à materialidade dos edifícios em si, para dar ensejo a uma política preservacionista vinculada não apenas à arquitetura, mas ao patrimônio enquanto desdobramento de uma dada cultura. Como colocou Márcia Chuva, ultrapassou-se "a perspectiva de uma identidade nacional una para se construírem valores com base na noção de diversidade cultural brasileira e de seus diferentes grupos de identidade, fundando um novo paradigma e, a partir daí, novas estratégias de ação" ${ }^{\prime 5}$. É, portanto, nesse contexto que a representação visual do patrimônio parece ter encontrado espaço não apenas para que se elaborasse uma memória do Iphan, mas para que a visualidade do instituto viesse servir, novamente, de meio pelo qual se pudesse organizar uma nova identidade para a cultura nacional.

\begin{abstract}
47. Em entrevista concedida ao autor, em 11 de dezembro de 2013, Lia Motta destaca que a Carta de Veneza acabou por ser incorporada em pareceres de Lygia Martins Costa. Ainda sobre esse aspecto, Flávia Brito, em artigo recentemente publicado, deixa clara a importância da Carta de Veneza para os trabalhos do Iphan. Ver Flávia Nascimento Brito (2014).
\end{abstract}

48. Presidente do Iphan entre 1967 e 1979.

49. Para mais detalhes a respeito desse processo, ver Maria Cecília Londres Fonseca (2005); Márcia Sant'ann (1995).

50. Ver Claudia Feierabend Baeta Leal (2008). Vale ainda destacar que Michel Parent escreveu um artigo no v. 19 da Revista do Iphan. Ver Michel Parent (1984).

51. Ver Isabelle Cury (2003).

52. Entrevista concedida ao autor.

53. Ver Márcia Regina Romero Chuva (2008).

54. Ver Isabelle Cury (2003).

55. Cf. Márcia Regina Romero Chuva (2008). 
56. Em 1970, o então Departamento do Patrimônio Histórico e Artístico Nacional (DPHAN) passou a ser designado como Instituto do Patrimônio Histórico e Artístico Nacional (Iphan), A nova designação diminuiu o poder de ação do IPHAN ao longo da década de 1970

57. Essa ação foi também um desdobramento do Compromisso de Brasília. Ver Márcia Regina Romero Chuva (2008).

58. Cf. Nabil Bonduki (2010, p.28).

59. Ibidem, p.29.

60. Ver Isabelle Cury (2003).
Mesmo com essa mudança de paradigma relativo ao patrimônio, especialmente no início dos anos 1970, o lphan continuava a ocupar um lugar de reduzido destaque na política federal, tendo forte diminuição de sua importância na estrutura ministerial do governo federal. Não é de se estranhar, portanto, que, justamente nesse período, ele tenha passado a dividir seu protagonismo com estados e municípios ${ }^{56}$. Assim, outras instituições ligadas à preservação foram criadas fora do âmbito federal, particularizando as ações em seus respectivos estados, como, notadamente, se percebe por meio da criação do lpac (1968), Condephaat (1968), lepha (1971) e Inepac (1975)57, respectivamente na Bahia, em São Paulo, Minas Gerais e no Rio de Janeiro, entre outras instituições. Com o desmembramento e a diluição entre federação, estados e municípios, o Iphan teve sua abrangência sensivelmente diminuída, o que se vê claramente, por exemplo, com os poucos números editados da revista do Iphan e com a significativa queda de incorporação de documentos ao Arquivo Fotográfico. Ainda no que se refere às políticas de preservação e a suas consequências para a trajetória do Iphan, parece relevante destacar a implementação do Programa Integrado de Reconstrução das Cidades Históricas - PCH -, criado em 1973, e que "objetivava a restauração de monumentos históricos, 'condicionada ao aproveitamento para fins turísticos, que deveria gerar as condições para sua manutenção"58. Destinado com exclusividade ao Nordeste brasileiro, visava a enfrentar o estado debilitado dessa região do país frente ao crescimento urbano desordenado, à industrialização desregulada e, ainda, a um turismo predatório. Nesse sentido, destacam-se alguns aspectos essenciais à compreensão não apenas do lugar ocupado pelo Iphan, mas, ainda, das sensíveis transformações no âmbito da cultura, no Brasil.

A estrutura governamental por trás do PCH bem revela o lugar do Iphan no início dos anos 1970. Compartilhado entre o Ministério do Planejamento, responsável pela coordenação do programa, o Ministério da Indústria, o Ministério do Interior, o Ministério do Comércio, por meio da Embratur, e o MEC, esse programa indica de maneira clara o lugar reduzido ocupado pelo Iphan, frente à premissa de desenvolvimento da economia. É certo que a participação desse instituto seria decisiva para a implementação do programa, visto que os projetos financiaram não apenas o restauro dos monumentos, mas a qualificação de mão de obra, o desenvolvimento de técnicas de preservação e restauro, a prospecção arqueológica, arquitetônica e pesquisa documental, a publicação de documento sobre a experiência de restauração específica, dentre outras atividades ${ }^{59}$. No entanto, a participação do instituto parece inserida apenas como a de assistência técnica, ao passo que aos outros ministérios interessava o desenvolvimento econômico da região, o real motivo para a implementação do PCH. Assim, o papel preeminente ocupado pelo Iphan, ao longo das primeiras três décadas, parece, mais uma vez, reduzido no início dos anos 1970. Nesse sentido, o aspecto econômico inerente ao $\mathrm{PCH}$, especialmente no que se refere ao turismo, vale ser ressaltado, uma vez que os debates em torno do patrimônio apontaram para essa direção já no ano de 1967, com a publicação da Carta de Quito ${ }^{60}$ 
elaborado pela Organização dos Estados Americanos (OEA), esse documento teve parte dedicada aos "Monumentos em Função do Turismo", ressaltando que:

A Conferência das Nações Unidas sobre Viagens Internacionais e Turismo (Roma, 1963) não somente recomendou que se desse alta prioridade aos investimentos em turismo dentro dos planos nacionais, como fez ressaltar que, "do ponto de vista turístico, o patrimônio cultural, histórico e natural das nações, constitui um valor substancialmente importante" e que, em consequência, seria urgente a "adoção de medidas adequadas dirigidas a assegurar a conservação e proteção do patrimônio"bl.

A elaboração do PCH parece, portanto, colocar em prática o que já havia sido indicado às políticas públicas ligadas ao patrimônio, em termos internacionais, fazendo com que o turismo passasse a ocupar um lugar de destaque para o governo federal. Tratava-se, por fim, da reorganização do lugar do lphan, no contexto nacional de políticas públicas, alterando de maneira profunda não apenas as políticas, mas a sua própria visualidade, agora, alinhando-o, em especial, a uma imagem a ser difundida e não necessariamente arquivada. Esse fato projeta novos significados para a escolha dos bons fotógrafos por parte de Lucio Costa, em texto publicado em 1986, e, também, para a associação de Herman Hugo Graeser a um trabalho autoral, justificando a referência a certos fotógrafos, como Pierre Verger, dissociados de uma narrativa documental e científica, própria às demandas do Iphan.

Frente ao prenúncio de organização de um novo lugar para o patrimônio no Brasil, parece fundamental compreender essa mudança não apenas na circunscrição do lphan, mas também no âmbito das políticas culturais brasileiras, que acabaram por intervir, sensivelmente, naquilo que se produziu a partir de então enquanto memória visual do patrimônio. Assim, como que no encontro de duas trajetórias, a do patrimônio e a das artes, a própria imagem da nação acaba por se reorganizar, projetando o que se entende hoje por visualidade, ligada à cultura e, por fim, ao patrimônio. Nesse sentido, se o lphan se encontrava num momento de profunda transformação e diminuição de seu papel na definição das políticas de estado, por outro lado, o cenário das artes era desencorajador, já que estagnado. Assim, como que visando reverter este quadro, o governo federal implementou uma série de ações, que redesenharam a política nos anos 1970, projetando, para as décadas seguintes, caminhos e significados para a produção cultural, como também ao patrimônio. Se acompanhadas as intervenções empreendidas pela Federação, nota-se a amplitude e a diversidade das ações que foram estabelecidas, para além de seus desdobramentos sobre o próprio lphan.

Das mais importantes realizações do governo, durante a Ditadura Militar, pela amplitude do programa e pelo volume de recursos empenhados, o Ministério da Educação e Cultura cria, em 1969, a Embrafilme que viria a regular, censurar e fomentar a produção e a distribuição do setor cinematográfico até o ano de 199062. Em 1972, criou-se o Departamento de Assuntos Culturais (DAC), que abriu espaço para a criação de dois outros programas: o Programa de Ação Cultural
62. Ano em que foi extinta pelo Programa Nacional de Desestatização (PND) do Governo Collor. 
63. Cf. Sergio Miceli (1984, p.55).

64. Segundo Miceli: "O surto recente de expansão do mercado de arte vinha suscitando a reação dos artistas, desejosos de instituir controles sobre modalidades de comercialização que lesavam seus interesses. Os leilões ativaram sem dúvida o mercado de obras de arte contemporânea, embora os preços alcançados pela maioria das obras fosse, via de regra, inferiores aos cobrados pelas galerias e marchands profissionais". Cf. Idem, p. 75 .

65. Ver Zoy Anastassakis (2007).

66. Disponível em: <http:// presrepublica.jusbrasil.com. br/legislacao/109137/lei5988-73>, acesso em: $27 \mathrm{dez}$. 2014.
(PAC) e o Conselho Nacional de Direito Autoral - CNDA. Esses três programas, em especial, marcam de maneira tenaz a vertente executiva ligada ao Estado. Foi com eles que o governo federal, diante da acentuada diminuição das ações e investimentos ligados à cultura nos anos 1960, buscou reestabelecer os investimentos. Miceli, ao tratar dos programas organizados pelo Estado, nos anos 1970, destacou que

○AC (...) não era apenas uma abertura de crédito, financeiro e político, a algumas áreas da produção cultural até então praticamente desassistidas pelos demais órgãos oficiais, mas também uma tentativa oficial de "degelo" em relação aos meios artísticos e intelectuais ${ }^{63}$.

Parece claro, portanto, que essas medidas vieram reestabelecer diálogos com os artistas, mesmo que ainda sob os olhos censores do Estado, preparando a abertura política, que viria a concretizar-se nos anos de 1980. Mas surge aqui uma sensível e importante mudança que irá repercutir profundamente na própria concepção do que se entende hoje como visualidade do Iphan e que, em certa medida, contribui para a própria formulação do arquiteto Lúcio Costa, em relação aos fotógrafos de lá.

Ao contrário do que vinha se elaborando desde a criação do MES, em 1930, o governo militar fomentou uma política cultural muito ligada às demandas particulares dos artistas e não mais ligada às especificidades do próprio ao Estado. Fruto de uma possível incapacidade do regime militar, aliada a um anseio da própria classe artística pela tomada da linha de frente de um crescente mercado ligado às artes, a política cultural dos anos 1970 parece, assim, ter transferido aos artistas a iniciativa da produção, dando início, de uma vez por todas, a uma política de valorização da produção autoral64. Ao Estado, atribuiu-se o papel de organizador das iniciativas, "reautorizando" aos artistas a liberdade de criação. Parece importante avaliar essa ação a partir da crise institucional pela qual passava - Estado, além da forte recessão econômica decorrente da crise mundial do petróleo, em 1973. Restava ao governo a atribuição de controle dos recursos destinados à cultura ${ }^{65}$. Nesse sentido, é relevante destacar o fato de que uma série de conselhos gestores foram criados nesse período, dentre os quais destaca-se o já mencionado Conselho Nacional do Direito Autoral - CNDA, ainda em 1973, responsável por "determinar, orientar, coordenar e fiscalizar as providências necessárias à aplicação das leis", em especial, a Lei n5988/7360, dedicada aos direitos autorais. A implementação dessa lei parece sensível na relação com o Iphan, uma vez que o uso que se fez da fotografia e a própria concepção do Arquivo Fotográfico esbarram em questões debatidas e organizadas por esse documento, como: reprodução, original e cópia. Esses termos são recorrentes ao cotidiano do Iphan não apenas pela dinâmica de produção, divulgação, circulação e uso cotidiano desse suporte documental, mas pela própria natureza a partir da qual o instituto pôde se firmar. Dinâmica assim se fez a partir da produção pormenorizada de fotografias dos edifícios tombados, a reprodução de quadros, livros, documentos e outros serviços solicitados aos servidores ou aos operadores 
e peritos em belas artes. Assim, é sensível que a Lei n5988/73 e, consequentemente, a política cultural dos anos 1970 tenham interferido de maneira determinante na ação e na dinâmica cotidiana do Iphan, mesmo que a sua aplicação tenha se dado de maneira lenta e gradativa, especialmente no que se refere aos direitos autorais vinculados à classe dos fotógrafos, que viria a se organizar de maneira mais clara a partir de 1984, com a criação do Instituto Nacional da Fotografia (INFoto/FUNARTE). De qualquer maneira, a interferência do CNDA parece ter desdobramentos sobre a própria incorporação de documentos ao Arquivo Fotográfico que, mais tarde, será notada na visualidade difundida pela própria instituição, o que irá interferir, também, na atribuição de valor a determinados conjuntos ou mesmo a determinados fotógrafos ${ }^{67}$.

As instituições e leis criadas pelo Estado foram ainda mais profundas para a cultura, no decorrer dos anos 1970. Criada em 1975, a Fundação Nacional das Artes (Funarte) foi também uma das instituições que mais contribuíram com o fomento de uma política cultural, dando especial atenção às ações particulares dos artistas, no campo da música, das artes plásticas e das artes visuais. "Destinada a atuar como incentivadora e divulgadora das artes nacionais"68, a Funarte desempenhou, nos anos 1970 e 198069, um papel chave na produção e na capacitação de artistas brasileiros, que, até então, tinham reduzido espaço frente à maciça entrada de produções estrangeiras. Assim como a criação do CNDA foi fundamental para a reorganização das atividades artísticas, a Funarte institucionalizou e organizou a produção cultural dos brasileiros, com profundas transformações também para a área da fotografia. Assim, em meados dos anos 1970, as artes passavam a um outro patamar, dando novo ar à cultura nacional. Desse cenário, a transformação final para o lphan e, também, para as artes de uma maneira geral, parece ter tido início com a criação do Centro Nacional de Referência Cultural (CNRC), não apenas pelas diretrizes sustentadas, mas também pela importância assumida no interior das pastas ministeriais.

\section{Redesenho institucional}

Organizado enquanto grupo de trabalho por meio de iniciativa conjunta de Severo Gomes, Ministro da Indústria e do Comércio (MIC), do designer Aloísio Magalhães ${ }^{70}$ e do Embaixador Wladimir Murtinho, Secretário da Educação do Distrito Federal, além de ter sido acolhido pela Fundação Universidade de Brasília, - CNRC ${ }^{71}$ desempenhou um papel imprescindível para a reorganização e uma reformulação da cultura brasileira, a partir de 1975. Já no ano seguinte à sua criação, os resultados e os indicativos positivos assinalados fizeram com que um convênio de cooperação técnica e financeira fosse firmado por distintos órgãos do governo, reforçando a importância assumida por esse projeto no governo federal. Secretaria do Planejamento da Presidência da República, MEC, MIC, Ministério das Relações Exteriores, Caixa Econômica Federal, Fundação Universidade de
67. Quanto à questão do direito autoral, especialmente em relação ao uso atual realizado pelo Iphan do material produzido ao longo das três primeiras décadas, ver entrevista realizada pelo autor com a arquiteta Lia Motta, 11 de dezembro de 2013.

68. "Uma boa ideia batizada Pixinguinha'”, disponível em: <http://www.funarte. g o v b b r / brasilmemoriadasartes/ acervo/pixinguinha/umabo a - id ei a - b a t i z a d a 'pixinguinha'/>. Acesso em: 27 dez. 2014.

69. Apesar de a Funarte ainda existir, restringe-se a leitura a esse período, uma vez que a fundação esteve extinta entre 1990 e 1992, e as s u mi outros particularidades ao longo de sua trajetória mais recente.

70. Aloísio Magalhães, advogado de formação, estuda museologia em Paris, no início da década de 1950. Em 1956, viaja aos Estados Unidos, onde se dedica às artes gráficas e à programação visual. Nesse período, publica com Eugene Feldman, os livros Doorway to Portuguese e Doorway to Brasília, que teriam grande impacto na cultura visual brasileira. A partir de 1960, no Brasil, produz uma série de trabalhos ligados às artes $\mathrm{e}$ à comunicação visual, como projetos para empresas e órgãos públicos, como Petrobrás, Eletrobrás, o primeiro logotipo da Rede Globo, o símbolo do $4^{\circ}$ Centenário do Rio de Janeiro e o símbolo da Fundação Bienal de São Paulo.

71. Ver Aloísio Magalhães (1985). 
72. Em entrevista realizada em 1979, Aloísio Magalhães indicara que "O país perde em autenticidade na medida em que importa tecnologia, fazer próprio". Ver João de Souza Leite (2014, p.161).

73. Ibidem. p.30.

74. Aqui, parece importante assinalar que esse programa de "levantamento de documentação relativa ao Brasil" reitera o programa de levantamento de representações artísticas já desenvolvido pelo Arquivo Fotográfico do Iphan. Da mesma maneira que os "artistas viajantes" eram tema recorrente nas pesquisas do Iphan, documentos associados a estes artistas foram levantados pelo CNRC, dando especial atenção ao "Brasil Holandês" e a "Documentação sobre as viagens de G. I. Langsdorff no Brasil". Ver Aloísio Magalhães (1985, p.62).

75. Cf. Zoy Anastassakis, 2007. Em Triunfos $e$ Impasses, Zoy destaca ainda a correlação entre os trabalhos e as concepções de design entre Aloísio Magalhães e Lina Bo Bardi. Ver Zoy Anastassakis (2014).

76. Em documento apresentado em 1978, Aloísio Magalhães define o que entende por "bens culturais": "... o conceito de bem cultural no Brasil continua restrito aos bens móveis e imóveis, contendo ou não valor criativo próprio, impregnados de valor histórico (essencialmente voltados para o passado), ou aos bens da criação individual espontânea, obras que constituem o nosso acervo artístico (música, literatura, cinema, artes plásticas, arquitetura, teatro) quase sempre de aplicação elitista (...). Permeando essas duas categorias, existe vasta gama de bens - procedentes sobretudo do fazer popular - que por estarem inseridos na dinâmica viva do
Brasília e Fundação Cultural do Distrito Federal foram os órgãos que se associaram a essa iniciativa a fim de promover e, também, se apropriar das ações e reflexões empreendidas pelo CNRC . Novamente, é possível notar não apenas a presença do MEC, de que se dava o vínculo com Iphan, mas de outros organismos de porte, no que se refere ao financiamento das ações, além de outros, vinculados ao desenvolvimento econômico, científico e intelectual, demonstrando o empenho do Estado com os programas desse centro. Vale destacar que essa ação não demonstra apenas uma iniciativa, mas também um interesse por parte do Estado, iá que se colocava enquanto alternativa para o desenvolvimento de uma indústria genuína e nacional, frente à crise institucional financeira. Tratava-se, portanto, do desenvolvimento de uma tecnologia própria à economia e à cultura brasileiras ${ }^{72}$.

O empenho na promoção do CNRC, aliado à criação de instituições como a Funarte, Embrafilme e outros mecanismos institucionais, assinalava o início da abertura política. Assim, uma avaliação das pesquisas e dos programas desenvolvidos pelo centro parece essencial no que se refere ao entendimento do que se formulou nos anos seguintes, enquanto reorientação das bases simbólicas da cultura nacional, a serem seguidas e fomentadas pelo governo, o que, por certo, contribuiu para a definição de uma memória visual para o lphan. Os objetivos iniciais do CNRC passavam por questões como o processo de desenvolvimento econômico do país, a preservação dos valores culturais, além do "papel do desenho industrial na definição de uma fisionomia própria dos produtos brasileiros"73 Assim, esse centro empenhou seus esforços no mapeamento da atividade artesanal, no levantamento sociocultural, na história da ciência e da tecnologia no Brasil e, por fim, no levantamento de documentação relativa ao país ${ }^{74}$. Com esses objetivos foram desenvolvidos programas como: a tecelagem popular no Triângulo Mineiro, a cerâmica de Amaro de Tracunhaém-PE, indústrias familiares de imigrantes em OrleansSC, artesanato indígena no Centro Oeste, artesanato de transformação, estudo multidisciplinar do caju, entre outros. Partindo do que Zoy Anastassakis chamou de "concepção antropológica da cultura"75, o CNRC deu ensejo aos domínios do ofício artesanal e às manifestações artísticas e criativas populares. Buscava-se, nesse cenário, o que se denominou de "referência cultural", dando atenção a certos "bens culturais" associados à identidade de determinados grupos, especialmente relacionados à cultura ameríndia e negra ${ }^{76}$. Deslocava-se, portanto, de uma concepção elitista e dominante da cultura, até então marcadamente presente no Brasil. Nesse aspecto, é notável que não só a materialidade dos bens era questão preeminente ao debate, mas, também, a identidade visual, a visualidade a ela circunscrita. Assim, da organização de uma base estabelecida pelo CNRC, a partir da qual a cultura nacional poderia se desenvolver e, por outro lado, de uma mudança de paradigmas na estrutura do Iphan, estas duas trajetórias parecem encontrar um destino comum, fazendo com que Aloísio Magalhães, até então diretor do CNRC, viesse a ser nomeado diretor do lphan, em 1979. Essa troca de cadeiras indica, por um lado, que o programa levado a cabo pelo designer estava em pleno acordo com o que o governo federal pretendia enquanto desenvolvimento da cultura, projetando, 
por fim, uma ação a ser implementada pelo próprio Iphan. Mas, por outro, também demonstra a mobilidade de Aloísio Magalhães nos circuitos de poder do Estado brasileiro, o que não já não se pode dizer de Renato Soeiro.

Logo após assumir a direção do Iphan, Aloísio Magalhães concedeu uma longa entrevista sobre as perspectivas de trabalho no instituto. Naquele momento, marcou não apenas a ligação de seu trabalho com o CNRC, mas, especialmente, as diretrizes a serem seguidas, que teriam sua gênese no anteprojeto elaborado por Mário de Andrade. Nessa entrevista, Aloísio Magalhães destacou que, a formação do patrimônio passava, naquele momento, a contar com um terceiro pilar, organizando uma triangulação entre "Mário, Capanema e Rodrigo"77, dando assim estabilidade às propostas do patrimônio. Dessa maneira, Aloísio buscava se desassociar do passado, muito vinculado à arquitetura, ao patrimônio de pedra e cal. No entanto, essa elaboração perspicaz, forjada pela associação com o primeiro superintendente do Iphan em São Paulo, parece ter validado não apenas a política que viria a implementar, mas, especialmente, a sua presença ali. Interessa notar que a inclusão de Mário de Andrade a uma gênese do patrimônio parece ter sido o álibi de Aloísio Magalhães para, finalmente, poder implementar políticas que já vinham sendo ensaiadas pelo próprio lphan em consonância com questões apresentadas pela Carta de Veneza (1967). Esse álibi parece ter sido necessário, já que, diante do domínio dos arquitetos, a única maneira de convencer e de se aproximar dos servidores do instituto seria dando algo que pertencesse à própria natureza dele, algo que não pudesse ser negado, mas acolhido. Não por menos, Aloísio Magalhães reforça, num discurso muito associado às práticas do CNRC, que a consciência do "caju ao monumento histórico, passando pela indústria de imigração europeia ou o artesanato industrial do interior do Nordeste" seria inerente ao serviço do lphan, uma vez que essas questões já estariam presentes no "documento original de Mário de Andrade"78. É nesse contexto que se elabora - livro Mário de Andrade: Cartas de Trabalho79, consolidando não apenas uma memória para o instituto, mas, também, atribuindo significado a Mário de Andrade e a uma ideia de cultura popular. Parece ter sido assim que Aloísio pôde tomar para si a direção simbólica e efetiva do lphan ${ }^{80}$.

A chegada de Aloísio Magalhães à direção estabelece uma grande diferença na dinâmica do Iphan. Acostumado com as dinâmicas dos ministérios e secretarias do governo federal, o novo diretor teria tido circulação facilitada, tornando possível a incorporação de novos investimentos. No entanto, vale aqui considerar que, se analisado a partir das narrativas externas, a designação de Aloísio Magalhães como diretor do instituto pode revelar uma busca por maior autonomia dos próprios conceitos ligados ao CNRC. Sobre isso, Aloísio Magalhães deixa claro que:

\footnotetext{
Agora eu já não me dirijo mais a uma entidade ou a uma associação, ou a uma coletividade como uma pessoa que dirige um projeto interessante, enriquecedor, etc. Eu me dirijo como diretor de uma instituição cuja legalidade é reconhecida pela nação, foi aprovada pelo Congresso Nacional e que durante 43 anos ela já tem a sua trajetória de critério, de valor técnico, etc. É como se a gente tivesse adquirido uma legenda que modifica, então, um posicionamento ${ }^{81}$.
}

cotidiano não são considerados como bens culturais nem utilizados na formulação de políticas econômica e tecnológica. No entanto, é a partir deles que se afere o potencial, se reconhece a vocação e se descobrem os valores mais autênticos de uma nacionalidade". Cf. Aloísio Magalhães (1985, p.19)

77. Cf. João de Souza Leite (2014, p.150).

78. Cf. João de Souza Leite (2014, p.181).

79. Ver Mário de Andrade (1981).

80. Vale notar que Aloísio Magalhães recorre a essa narrativa em diversos textos e entrevistas. Não se trata, portanto, de um apontamento único ou de uma passagem qualquer, mas de uma narrativa que vai se firmando ao longo dos discursos.

81. Cf. João de Souza Leite (2014, p.187). 
82. Ver Aloísio Magalhães (1985, p.113).

83. Vale destacar que, mesmo que a atuação de Renato Soeiro a frente da direção do Iphan (1967 e 1979) seja reconhecidamente importante para a trajetória da instituição, o que pode ser considerado frente às parcerias estabelecidas em âmbito internacional com a Unesco ou mesmo por meio do "Curso de Especialização em Conservação de Monumentos Históricos" (1974), é certo que o poder de ação desse instituto havia sido reduzido ao longo da Ditadura Militar. Assim, mesmo havendo evidências de transformação dos discursos e metodologias de ação, elas não parecem ser suficientes para se entender esse momento como um processo de modernização do Iphan. Ao contrário, parece tratar-se de um período de ação reduzida, como indicam os poucos números publicados da Revista do Patrimônio no período.

84. Especialmente a questão do Patrimônio Cultural, indicada pela Carta de veneza.

85. Godofredo Filho apresenta um texto sobre o "ecletismo", o que, até então, não havia merecido o real destaque, e Lúcio Costa apresenta um texto de Le Corbusier, reiterando uma narrativa "clássica" da história da arquitetura. Ver Le Corbusier (1984).
Aloísio Magalhães reconhece, nessa entrevista, que, de dentro do Iphan, poderia por em prática aquilo que não teria sido possível ao longo dos quatro anos em que esteve a frente da direção do CNRC - um Centro sem grandes liberdades de atuação, especificamente no que se refere à questão financeira. Nesse sentido, mesmo sem ter pleiteado o cargo ${ }^{82}$, Aloísio Magalhães parece ter se apropriado da estrutura do Iphan, que vinha tendo atuação discreta frente ao desmonte provocado pela Ditadura Militar ${ }^{83}$. Como consequência, interrompeu-se uma narrativa e um cotidiano já consolidados, pondo a frente ideias e projetos gestados, em grande parte, dentro do âmbito dos programas governamentais ligados à cultura. Por outro lado, os debates iniciados no lphan ${ }^{84}$, associados à Carta de Veneza ou à Carta de Quito, parecem também reconhecidos e absorvidos pela atuação de Aloísio, fazendo com que a sua entrada seja tomada mais naturalmente pelos servidores do órgao. A proximidade entre os debates do CNRC e do Iphan fez com que essa mudança efetiva fosse absorvida, aparentemente, com certa naturalidade. Nesse contexto, é notável que a revista do Iphan tenha se dedicado a temas mais associados à cultura, deixando de lado uma narrativa predominantemente ligada à arquitetura.

número 19 da Revista do Patrimônio, tomado como um relançamento da revista pelo seu editorial, apresentou formato e projeto gráfico renovados. Assim, em 1984, o Iphan relançava a sua principal publicação, demonstrando não apenas nos temas, mas também nas abordagens que o pensamento ligado à preservação do patrimônio já seguia outros rumos. Mesmo que ainda com uma forte presença associada a uma narrativa da arquitetura e, em especial, aos grandes nomes do patrimônio, como Godofredo Filho e Lúcio Costa ${ }^{85}$, outros temas até então ausentes aparecem pela primeira vez, como: "a preservação através da política de solo urbano", tomada a partir de textos de Silva Telles e Mauricio Nogueira Baptista; a "ecologia e a natureza", compreendida como patrimônio cultural, a partir de textos de Antônio Luiz Andrade, lêda Carneiro e Ângela Quintão; e, por fim, o "artesanato" enquanto meio de identidade cultural do povo brasileiro, em texto de Lélia Soares. Os números que se seguiram foram ainda mais específicos dedicando-se a temas como a questão indígena, a cidadania, o negro, a fotografia, a arte e a cultura popular, dentre outros. Pode-se, portanto, pela própria trajetória da revista, compreender a mudança que se operou no lphan, a partir de 1979, trazendo novos debates e, especialmente, autores vindos de áreas diversas como sociologia, antropologia, história, geografia e as artes. Vale ressaltar, no entanto, que essa transformação, que já vinha sendo organizada no instituto desde o final dos anos 1960, pôde se realizar, ao menos na Revista do Patrimônio, apenas com as mudanças organizadas, a partir de 1979, quando o Iphan passou a ser tomado dentro de outra perspectiva por parte do governo federal.

No ano de 1979, o lphan foi desmembrado em duas instituições: a Secretaria do Patrimônio Artístico e Nacional (Sphan) e a Fundação Nacional PróMemória, um braço executivo do MEC, responsável pela destinação e mobilização das verbas dessa pasta ministerial. Por esse braço executivo, Aloísio Magalhães 
trouxe para esse espaço instituições como o Museu Histórico Nacional, a Biblioteca Nacional e o Iphan, além do Programa das Cidades Históricas e o próprio CNRC, desenhando o que viria a ser a Secretaria de Cultura do MEC, criada alguns anos depois, em $1981^{86}$. Assim, essas instituições passaram a receber incentivos mais contundentes, promovendo suas atividades, de uma maneira geral. Importa ainda notar que, assim como o CNRC, o Programa das Cidades Históricas (PCH), até então sob a coordenação da Secretaria de Planejamento da Presidência da República, passou a ser de responsabilidade do lphan, mobilizando importantes recursos para o instituto. A mudança desse programa para a rotina do lphan fez, também, com que emergissem os debates relacionados ao turismo, muito em pauta a partir da Carta de Quito e de grande interesse por parte de Aloísio Magalhães. Dentro desse programa, a "recuperação vocacionada das cidades históricas", o designer destacava, em 1979, que: "havia uma indicação precisa de que seria um elemento enriquecedor da região em termos de recursos econômicos - a ênfase do turismo e, portanto, o melhor rendimento do turismo - se o bem cultural estivesse recuperado" 87 . Essa passagem deixa claro que o conceito de "bem cultural", organizado a partir do CNRC, acabou por se expandir, em grande medida, no Iphan, mobilizando não apenas as ações diretamente destinadas à recuperação das cidades e dos bens tombados ou à manutenção de uma integridade da materialidade, mas, também, a mobilização e promoção de atividades econômicas ligadas ao turismo, nas quais a fotografia viria a servir como instrumento decisivo.

Uma nova linguagem visual para o patrimônio

A mudança de abordagens referente à cultura nacional e, consequentemente, à própria estrutura de ação do lphan acabou por projetar uma mudança, também, na linguagem visual ali elaborada e arquivada. É certo que houve a necessidade da manutenção de um serviço de documentação da arquitetura e das cidades, já que o patrimônio material tombado era, naquele momento, amplo, expressivo e de grande notoriedade nacional. Tratava-se, portanto, de um serviço a ser, inevitavelmente, preservado. Assim, os procedimentos de documentação e inventário para os tombamentos tiveram que ser mantidos, já que intrínsecos à própria lógica de tombamento do Iphan. No entanto, o que se revela nesse momento é que uma outra imagem associada ao patrimônio passou a ser necessária aos serviços. Não apenas a fotografia em intrínseco diálogo com a arquitetura, com sua linguagem própria destinada a um arquivamento técnico do bem, mas, agora, tratava-se de produzir e, especialmente, divulgar uma imagem tomada a partir de outra linguagem, muito mais associada ao fotojornalismo ou, em alguns momentos, próxima a uma imagem publicitária. Nota-se, portanto, que essas mudanças de abordagens forçaram com que outros protocolos visuais passassem a ser abordados pelo Iphan, "desnaturalizando" um certo padrão científico recorrente ao cotidiano de produção fotográfica no instituto e, assim,
86. Ver Maria Cecília Londres (2003).

87. Cf. João de Souza Leite (2014, p.154). 
88. Francisca Helena Barbosa; Mônica Muniz Melhem; Oscar Henrique Liberal (org.), 2008. p.52.

89. Fotógrafo estadunidense, no início dos anos 1960, trabalhou como técnico do laboratório do importante fotógrafo de moda Irving Penn. Em 1968, transfere-se para o Brasil, passando a trabalhar como fotógrafo da Revista Manchete. Em 1970, trabalha como freelancer no Rio de Janeiro, trabalhando, em especial para estúdios de publicidade. Em 1980, montou um importante curso de fotografia, baseado nos 12 volumes publicados pela Life-Time, formando mais de 300 fotógrafos. Em 1988, retornou aos Estados Unidos. instaurando um novo projeto para seu arquivo. A abrangência dos temas impôs outros recursos, linguagens e técnicas de documentação mais ligados ao imaginário cotidiano da população. Da mesma maneira que a abordagem do patrimônio, agora candente sob a perspectiva da cultura popular, da cultura ameríndia ou mesmo de uma abordagem ligada ao turismo, a linguagem fotográfica teve também que se adequar a essas novas narrativas, o que será notado não apenas nas publicações, mas nos próprios documentos incorporados ao Arquivo Fotográfico, a partir do início dos anos 1980. Essa imagem condizente com as produções e debates do Iphan se deu, novamente, com a contribuição de vários fotógrafos. Nesse caso, uma considerável parte da documentação fotográfica apropriada pelo instituło passou a vir de mídias impressas, já que, em muitos casos, tratava-se da representação e do uso de imagens de cenas cotidianas, manifestações populares e outras demonstrações pertencentes ao imaginário da população. Mas é na trajetória do fotógrafo Pedro Lobo, um dos grandes responsáveis pela produção imagética do Iphan nos início dos anos 198088, que se pode compreender algumas das questões por trás dessa organização de uma outra visualidade.

O fotógrafo Pedro Lobo, ainda em meados dos anos 1970, foi contratado por Aloísio Magalhães para documentar projetos ligados ao CNRC. Fotografou o artesanato indígena da aldeia Krahô, num projeto coordenado pelo antropólogo George de Cerqueira Leite Zarur e, posteriormente, por Roberto Cardoso de Oliveira, além de aldeias Kadiwéu e Carajás. É portanto nesse momento que, além de tomar contato com o designer Aloísio Magalhães, se aproxima dos temas e das abordagens condizentes com a política do centro. Vale destacar que Pedro Lobo, ainda jovem fotógrafo, foi formado por um atuante fotógrafo estadunidense, Dick Welton ${ }^{89}$, residente no Rio de Janeiro e contratado como freelancer pela Revista Manchete, no final da década de 1970.

Assim, é notável que parte da sensibilidade fotográfica de Pedro Lobo venha carregada pelo fotojornalismo, mas, também, de referências ou de uma estética ligada à publicidade, iá que Welton prestou serviços a agências publicitárias, na capital fluminense, ao longo dos anos 1970 e 1980. Além de uma rápida passagem num curso de arquitetura, Pedro Lobo parece ter também se familiarizado cedo com a história da arte, disciplina ministrada por sua mãe, Henda da Rocha Freire, ex-professora da UFRJ. A formação desse fotógrafo é notável e bem serve para indicar a pluralidade temática com a qual esteve em diálogo, o que, certamente, the exigia um amplo conhecimento técnico, condizente com as demandas do CNRC. Com a indicação de Aloísio Magalhães para a direção do lphan, em 1979, o designer acaba por contratar Pedro Lobo como fotógrafo efetivo e vinculado à Fundação Pró-Memória, de onde poderia requerer de maneira mais ágil fundos para a realização da documentação fotográfica.

O serviço realizado por Pedro Lobo aparece em momentos diversos das atividades do lphan e a variedade das temáticas e abordagens revela os novos caminhos tomados pelo instituto. A Revista do Patrimônio de número 20 dedicada, em especial, ao restauro do Paço Imperial e ao futuro da Praça XV, trouxe um artigo 
do jornalista e escritor João Antônio, em que o autor expunha, em tom pessimista, algumas de suas memórias, além de constatações das atuais condições daquele logradouro da antiga capital ${ }^{90}$. Detalhando lugares, passagens e tipos sociais, nota-se que o artigo não aponta apenas para o tom pessimista que assume a narrativa estabelecida pelo autor, mas dá destaque a um certo cotidiano familiar, a uma memória reconhecível pela população. Assim, o conjunto de fotos apresentadas por Pedro Lobo ${ }^{91}$, além de dar conta de uma leitura urbana da praça, onde se vê a Avenida Perimetral, a estação das barcas, o aeroporto e a Baía de Guanabara, traz um contundente registro dos tipos sociais, especialmente ligados a pequenos comércios, como registrado na página 125 da revista (Figura 2). Numa linguagem muito próxima à do fotojornalismo, representa o interior de uma tabacaria, onde clientes e vendedores dividem o balcão rodeado de caixas de cigarro e fumos de corda. $\bigcirc$ interior de um bar, o balcão de uma pequena relojoaria e uma cena da praça, onde mulheres conversam ao lado da barraca de um comércio informal dão o tom a uma narrativa muito distante daquela comumente associada à pedra e cal, contribuindo, por fim, com uma imagem de sociabilidade, característica àquela praça.
90. Ver João Antonio (1984, p.123-126).

91. Há, ainda, uma foto realizada por Eduardo Mello, assistente de Pedro Lobo, que viria a ser chefe do arquivo de fotografias na Superintendência de São Paulo, como indicado pelo fotógrafo, em entrevista concedida ao autor, em 11 de setembro de 2012 .

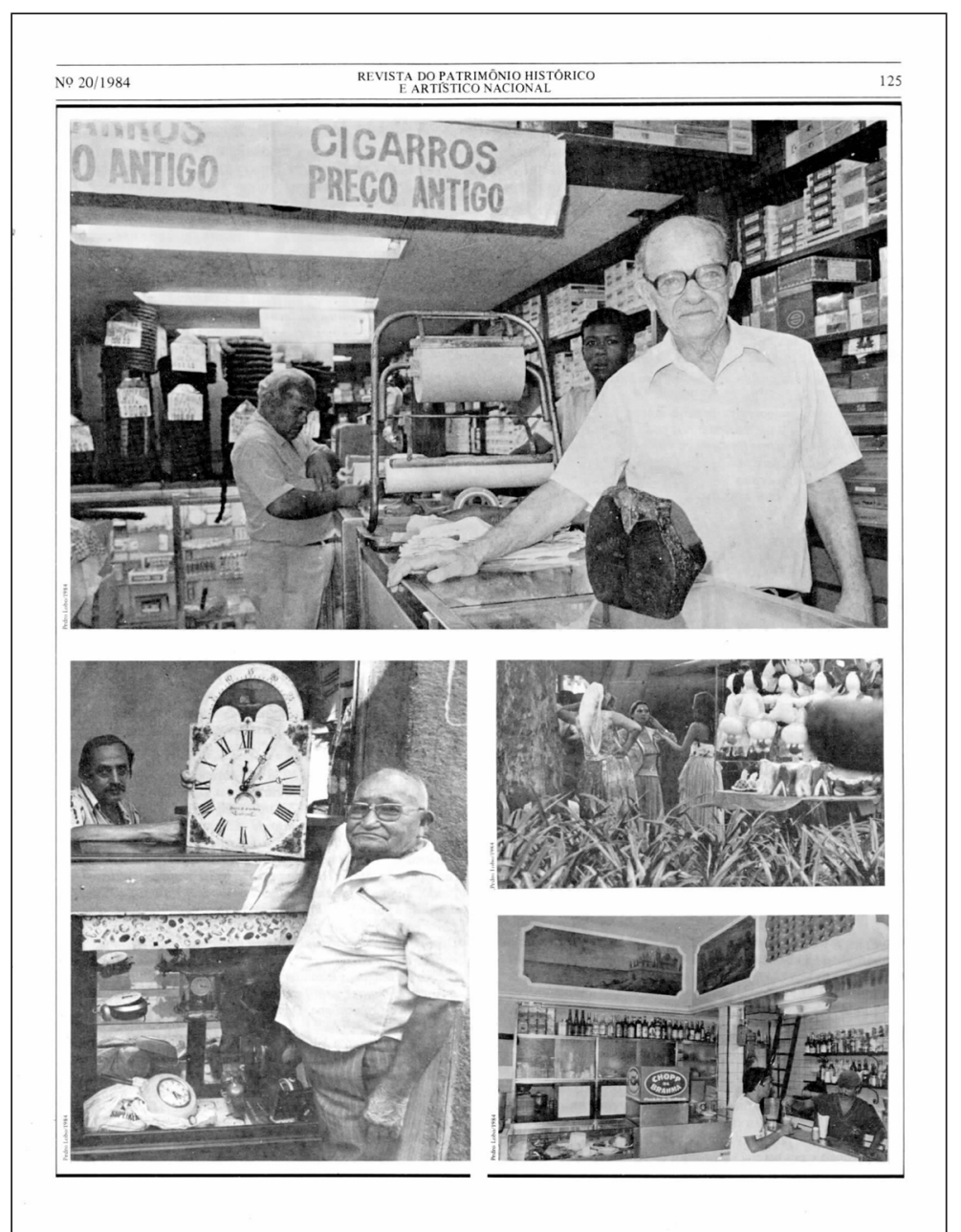

Figura 2 - Fotografia de Pedro Lobo em página do artigo "Praça XV, Ai!" publicado na Revista do Patrimônio Histórico e Artístico Nacional, em 1984. 
92. Arquivo Fotográfico do IPHAN. Peças de Arte Plumária, 16. Foto: 106.445 - Museu Nacional 13578, Kaiabi.

93. Entrevista concedida ao autor, em 1 de outubro de 2012.

94. Olinda foi tombada como Patrimônio Histórico Mundial pela Unesco no ano de 1982.
A linguagem apresentada pelos documentos fotográficos realizados por Pedro Lobo nesse artigo da revista do Iphan dá conta de apresentar a mudança organizada na estrutura do instituto, no início dos anos 1980, o que, em grande medida, destaca uma transformação operada por meio do Estado, no processo de reabertura política. No entanto, ao avaliar o Arquivo Fotográfico, nota-se que perduraram certas práticas e rotinas ligadas a um cotidiano desse serviço. Chama a atenção uma série de documentos fotográficos relativos às peças de arte plumária pertencentes ao Museu Nacional. Constituído com uma clara intenção de organizar um inventário dessas peças, esse conjunto bem representa a manutenção de uma prática do Iphan, destinada a arquivar reproduções de documentos e peças dos acervos dos museus do país. Vale destacar, portanto, que não apenas uma imagem associada às manifestações ou bens culturais passava pelo interesse do instituto, no início dos anos 1980. Manteve-se, ainda, a produção de uma fotografia mais técnica, dedicada à reprodução e à documentação dos acervos museológicos. Quanto a esse aspecto, nota-se que Pedro Lobo manteve um rigor necessário ao serviço, os protocolos, documentando flechas, adereços e cocares com uma luz homogênea sob um suporte de médio formato, captando os objetos com a apropriada riqueza de detalhes. Características que podem ser vistas, por exemplo, no documento fotográfico 106445 (Figura 3), no qual um cocar aparece bem disposto sobre uma bancada de tom claro e homogêneo, contrastando com o objeto e, assim, facilitando a sua leitura e preservação ${ }^{92}$. Vale ainda notar que, apesar de mantido o procedimento técnico necessário e inerente a esse serviço, os objetos documentados são especialmente novos, mas muito condizentes com o conjunto de interesses dos servidores do Iphan, a partir do início da década de 1980.

Ainda, é sensível que esse fotógrafo revele procedimentos de documentação mais dinâmicos e mais libertos de uma rigidez documental própria e necessária aos primeiros anos do arquivo, distanciando sua prática daquela associada aos fotógrafos mais diretamente ligados a um trabalho de estúdio, como Herman Hugo Graeser ou Kasys Vosylius. Nesse sentido, em relação ao processo de documentação de obras do Museu de Arte Sacra, na companhia da antropóloga e diretora do Instituto Nacional do Folclore da Funarte, Lélia Contijo Soares, o fotógrafo apontou o seguinte: " ... ela entrava no museu e ela falava: 'Fotografa isso, aquilo, aquilo, aquilo e aquela outra...'. E eu olhava para ela [em tom de desaprovação]. Eu sempre fui um rebelde danado"93. Se a liberdade documental apresentada por esse fotógrafo do Iphan parece revelar uma mudança de abordagem no procedimento documental, ao longo da primeira metade da década de 1980, deve-se notar a manutenção da interlocução entre os fotógrafos e os servidores, atentos àquilo que deveria ser registrado e arquivado, buscando uma narrativa condizente com o proposto. Ainda nesse sentido, Pedro Lobo destaca, em outra passagem, as solicitações feitas por Aloísio Magalhães sobre certos aspectos que deveriam estar presentes na documentação relativa à candidatura de Olinda a patrimônio mundial da Unesco (Figura 4) ${ }^{94}$. Segundo o fotógrafo: "... o Aloísio deu muito 'input'. 'Tem que fotografar os fiteiros', que são os ambulantes. 


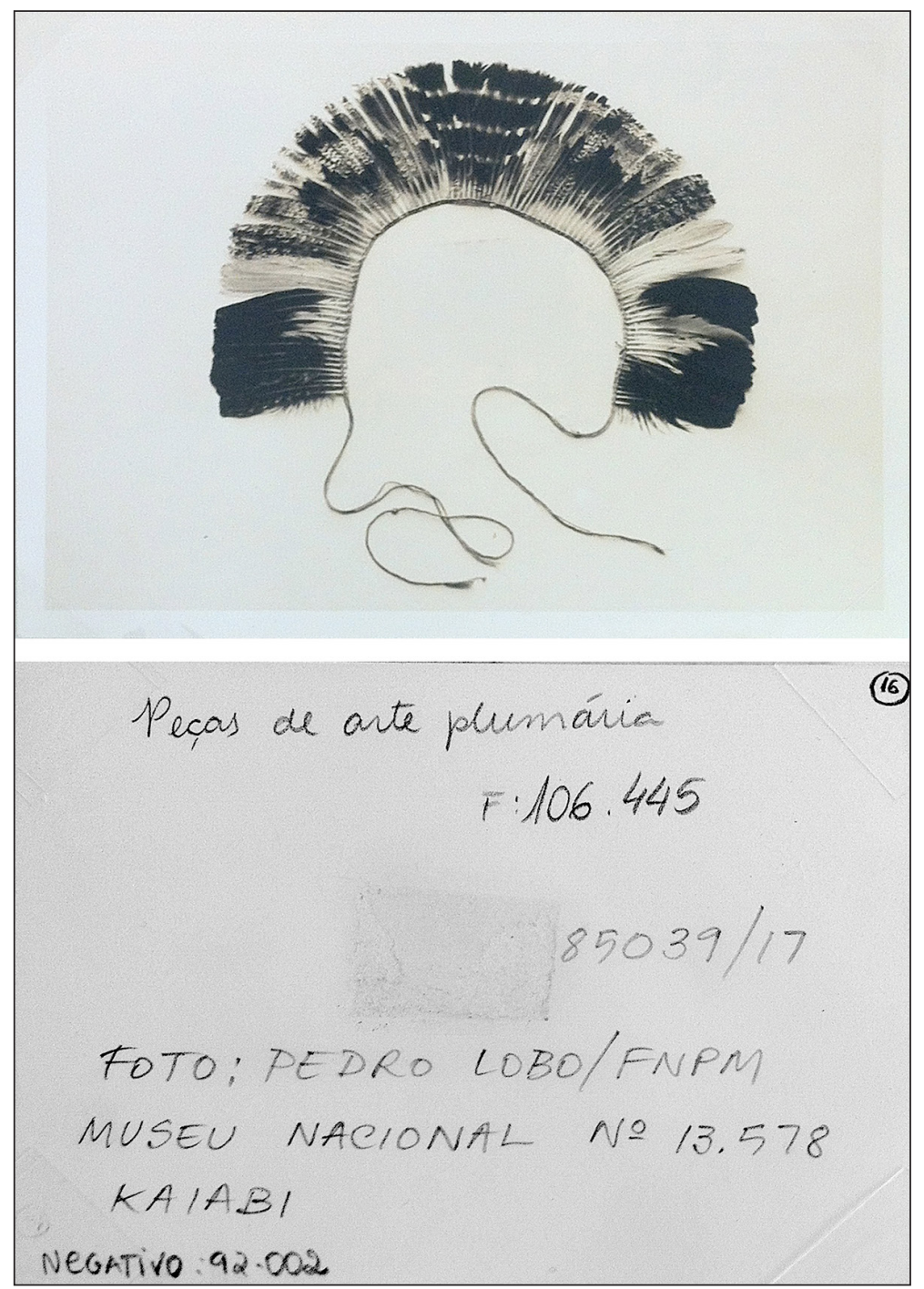

95. Entrevista concedida ao autor, em 1 de outubro de 2012.

Figura 3 - Fotografia de Pedo Lobo. Peças de Arte Plumária, 16. Foto: 106.445 - Museu Nacional n. 13578, Kaiabi. Arquivo Fotográfico do Iphan.

'Pegue o pessoal jogando bola'. Ele deu toda outra vertente, que contrabalançava com o Silva Telles"95.

Da parte de Aloísio Magalhães, houve portanto, o cuidado de solicitar ao fotógrafo que documentasse aquilo que poderia caracterizar um cotidiano da população da cidade de Olinda, para além da documentação da arquitetura e dos espaços urbanos, ligados a uma vertente mais tradicional do Iphan, associada ao arquiteto Silva Telles. Assim, garantia-se à documentação uma caracterização para além do patrimônio material, ajustando a narrativa para aquilo que já se apresentava através do CNRC e, portanto, alinhada com as intenções do governo federal. Por fim, vale reforçar a importância assumida pelo fotógrafo, no processo 
96. Ver Gisela Abad (2011, p.119). de transformação da própria condição do Iphan, a partir dos anos 1970. Seria não apenas pela intenção de renovação e pelos novos debates travados ali, mas, em especial, pela contribuição desse jovem fotógrafo para a efetivação de uma mudança na dinâmica do Iphan, estruturada no interior do seu Arquivo Fotográfico.

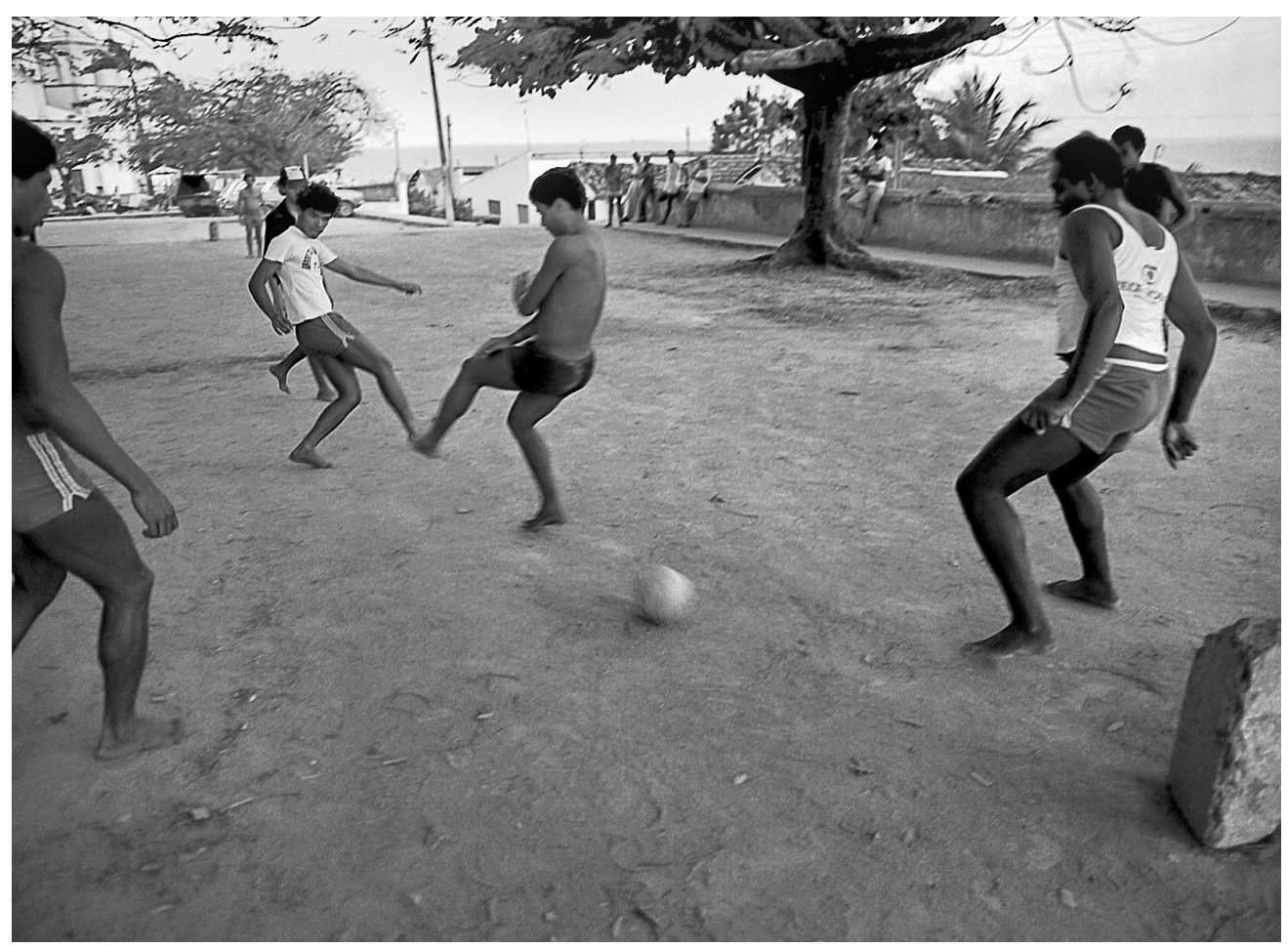

Figura 4 - Fotografia de Pedro Lobo que integra o ensaio realizado para a candidatura de Olinda como Patrimônio Mundial da Humanidade, em 1981. Rua do Amparo - Olinda\%.

A produção fotográfica de Pedro Lobo permite, portanto, compreender não apenas aquilo que o Iphan projetou para si a partir dos anos 1980, mas, principalmente, o desdobramento no seu interior de uma imagem gestada no momento de reabertura políitica do país. O Arquivo Fotográfico do Iphan revela, assim, uma transformação posta em prática entre os anos 1970 e 1980, na qual - autor fotógrafo desempenhou um papel chave na elaboração dos discursos desejados. Distanciava-se, assim, de uma visualidade ligada à arquitetura e à cultura material, para se associar a um discurso visual mais ligado ao fotojornalismo ou mesmo à publicidade. Mudança que dá ensejo a uma narrativa do patrimônio colocada em pauta nos anos 1970, em que não apenas o turismo assumia papel preeminente, mas também a Cultura Imaterial adquiria importante relevância nos trabalhos desenvolvidos pelo Iphan. Assim, da mesma maneira que, no início de sua trajetória, o Arquivo Fotográfico serviu ao Iphan como meio de organizar conceitos ligados ao patrimônio de "pedra e cal", com as mudanças presentes no viés patrimonial, identificáveis em programas como o PCH, foi também esse arquivo 
um dos mais importantes instrumentos responsáveis pela organização e manutenção de um discurso para a trajetória recente do Iphan. Mais uma vez, foi por meio do Arquivo Fotográfico que se pôde instituir balizas para o processo de consolidação de certas ideias, além de ações futuras, ainda hoje recorrentes na prática de uma comunidade ligada à preservação no Brasil.

\section{REFERÊNCIAS}

ABAD, Gisela (org.). Linda Olinda. Recife: Caleidoscópio, 2011. Fotografias de Pedro Lobo.

ALPERS, Svtlana. A arte de descrever: a arte holandesa no século XVII. São Paulo: EDUSP, 1999.

ANASTASSAKIS, Zoy. Dentro e fora da política oficial de preservação do patrimônio cultural no Brasil: Aloísio Magalhães e o Centro Nacional de Referência Cultural. 2007. Dissertação (Mestrado) - Programa de Pós-Graduação em Antropologia Social, Museu Nacional, Universidade Federal do Rio de Janeiro, Rio de Janeiro, 2007.

Triunfos e impasses: Lina Bo Bardi, Aloísio Magalhães e o design no Brasil. Rio de Janeiro: Lamparina; FAPERJ, 2014.

ANDRADE, Rodrigo Melo Franco de. A pintura colonial em Minas Gerais. Revista do Patrimônio Histórico e Artístico Nacional, Rio de Janeiro, v. 18, p.11-74, 1978.

Rodrigo e seus tempos: coletânea de textos sobre artes e letras. Rio de Janeiro: Ministério da Cultura; Fundação Nacional pró-Memória, 1986.

Rodrigo e o SPHAN. Rio de Janeiro: Ministério da Cultura; Fundação Nacional próMemória, 1987.

ANDRADE, Mário de. Mário de Andrade: Cartas de trabalho - correspondência com Rodrigo Mello Franco de Andrade, 1936-1945. Brasília: Secretaria do Patrimônio Histórico e Artístico Nacional; Fundação pró-Memória, 1981.

ANGOTTI-SALGUEIRO, Heliana. Marcel Gautherot na revista Módulo - ensaios fotográficos, imagens do Brasil: da cultura material e imaterial à arquitetura. Anais do Museu Paulista: História e Cultura Material, São Paulo, v.22. n.1, p.11-79, jan.-jun. 2014.

ANTONIO, João. 'Praça XV, Ai!'. Revista do Patrimônio Histórico e Artístico Nacional, Rio de Janeiro, v. 20, p.123-126, 1984.

BAUMGARTEN, Jens; TAVARES, André. O Barroco colonizador: a produção histórico-artística no Brasil e suas principais orientações teóricas. Perspective, Paris, n.2, 2013. Disponível em <https://perspective.revues.org/5538>, acesso em 28 dez. 2014

BAXANDALL, Michael. O olhar renascente: pintura e experiência social na Itália da Renascença. Rio de Janeiro: Paz e Terra, 1991. 
BAXANDALL, Michael. Giotto and the Orators: Humanist Observers of Painting in Italy and the Discovery of Pictural composition 1350-1450. Oxford: The Clarendon Press, 1971.

BONDUKI, Nabil. Intervenções urbanas na recuperação de centros históricos. Brasília, DF: Iphan; Programa Monumenta, 2010.

BRASIL. Decreto-Lei no 25 , de 30 de novembro de 1937. Organiza a proteção do patrimônio histórico e artístico nacional. Rio de Janeiro, 30 de novembro de 1937. Disponível em: https:// www.planalto.gov.br/ccivil_03/decreto-lei//Del0025.htm, acesso em: 09 jun. 2015.

BRASIL. Lei $\mathrm{n}^{\circ}$ 5.988, de 14 de dezembro de 1973. Regula os direitos autorais e dá outras providências. Brasília, 14 de dezembro de 1973. Disponível em: http://www.planalto.gov.br/ ccivil_03/leis/L5988.htm, acesso em: 27 dez. 2014.

BRASIL. Ministério da Cultura. Funarte. Uma boa ideia batizada Pixinguinha. Brasil: memória das artes. 2013. Disponível em: <http://www.funarte.gov.br/brasilmemoriadasartes/acervo/ pixinguinha/uma-boa-ideia-batizada-'pixinguinha'/>, acesso em: $27 \mathrm{dez}$. 2014.

BRITO, Flávia Nascimento. Em busca de novos documentos: cidade, história e fontes de pesquisa na prática do IPHAN dos anos 1980. In: Enanparq, III, 2014, São Paulo. Anais do III Encontro da Associação Nacional de Pesquisa e Pós-Graduação em Arquitetura e Urbanismo. São Paulo: Mackenzie, 2014.

CANCLINI, Nestor Garcia. Culturas híbridas: estratégias para entrar e sair da modernidade. São Paulo: Edusp, 2008.

CARTA de Veneza: carta internacional sobre conservação e restauração de monumentos e sítios. Revista do Patrimônio Histórico e Artístico Nacional, Rio de Janeiro, v. 22, p.106-107, 1987.

CHUVA, Márcia Regina Romero. O ofício do historiador: sobre ética e patrimônio cultural. In: Oficina de Pesquisa: a pesquisa histórica no IPHAN, I, 2008, Rio de Janeiro. Anais... Rio de Janeiro: Iphan; Copedoc, 2008.

COSTA, Eduardo Augusto. Arquivo, Poder, Memória: Herman Hugo Graeser e o Arquivo Fotográfico do IPHAN. 2015. Tese (Doutorado) - Departamento de História. Instituto de Filosofia e Ciências Humanas, Universidade Estadual de Campinas, 2015.

COSTA, Helouise (org.). As origens do fotojornalismo no Brasil: um olhar sobre O Cruzeiro. São Paulo: Instituto Moreira Salles, 2012.

COSTA, Lúcio. Prefácio. In: ANDRADE, Rodrigo Melo Franco de. Rodrigo e seus tempos: coletânea de textos sobre artes e letras. Rio de Janeiro: Ministério da Cultura; Fundação Nacional Pró-Memória, 1986, p.5-10.

CURY, Isabelle (org.). Cartas patrimoniais, $3^{a}$ ed.. Brasília: Iphan, 2003. Coleção Edições do Patrimônio.

DERRIDA, Jaques. Archive Fever: a Freudian Impression. The University of Chicago Press: Chicago, 1995. 
ESPADA, Heloisa. Fotografia, arquitetura, arte e propaganda: a Brasília de Marcel Gautherot em revistas, feiras e exposições. Anais do Museu Paulista: História e Cultura Material, São Paulo, v. 22. n.1, p. 81-105, jan.-jun. 2014.

FERREZ, Gilberto. A fotografia no Brasil e um dos seus mais dedicados servidores Marc Ferrez (1843-1923). Revista do Patrimônio Histórico e Artístico Nacional, Rio de Janeiro, v. 10, p.169-304, 1953.

FONSECA, Maria Cecília Londres. O Centro Nacional de Referência Cultural: a contemporaneidade do pensamento de Aloísio. In: SOUZA LEITE, J. A herança do olhar: o Design de Aloísio Magalhães. Rio de Janeiro: Senac; Artviva, 2003.

O patrimônio em processo: trajetória da política federal de preservação no Brasil. Rio de Janeiro: UFRJ; Minc; Iphan, 2005.

FOUCAULT, Michel. A arqueologia do saber. Rio de Janeiro: Forense Universitária, 2009.

FLIEG. São Paulo: Instituto Moreira Salles, 2014. Catálogo da exposição.

GORELIK, Adrián. Das vanguardas a Brasília: cultura urbana e arquitetura na América Latina. Belo Horizonte: Editora UFMG, 2005.

HESS, Erich. Isto é Brasil! São Paulo: Melhoramentos, s/d.

KNAUSS, Paulo. O desafio de fazer História com imagens. Arte e cultura visual. ArtCultura, Uberlândia, v. 8, n. 12, p. 97-115, 2006.

KOSSOY, Boris. Hercules Florence, 1833: a descoberta isolada da fotografia no Brasil. São Paulo: Faculdade de Comunicação Social Anhembi, 1976.

LEAL, Claudia Feierabend Baeta. As missões da Unesco no Brasil: Michel Parent. Rio de Janeiro: Iphan; Copedoc, 2008.

LE CORBUSIER. A arquitetura e as belas-artes. Revista do Patrimônio Histórico e Artístico Nacional, Rio de Janeiro, v. 19, p.53-69, 1984.

LEITE, João de Souza (org.). Encontros: Aloísio Magalhães. Rio de Janeiro: Beco do Azougue, 2014.

LIMA, Francisca Helena Barbosa; MELHEM, Mônica Muniz; BRITO E CUNHA, Oscar Henrique Liberal (coord.). A fotografia na preservação do patrimônio cultural: uma abordagem preliminar. Cadernos de pesquisa e documentação do IPHAN, Rio de Janeiro, v. 4, 2008.

MAGALHÃES, Aloísio. E triunfo?: a questão dos Bens Culturais do Brasil. Rio de Janeiro: Editora Nova Fronteira; Fundação Nacional pró-Memória, 1985.

MAGAlHÃES, Aloísio; FELDMAN, Engene. Doorway to Brasília. Filadélfia: Falcon Presse; Nova York: Wittenborn, 1957a.

Doorway to Portuguese. Filadélfia: Falcon Presse; Nova York: Wittenborn, 1957b. 
MENESES, Ulpiano T. Bezerra de. Fontes visuais, cultura visual, História visual. Balanço provisório, propostas cautelares. Revista Brasileira de História, São Paulo, v. 23, n. 45, p. 1136, 2003.

MICELI, Sergio. SPHAN: refrigério da cultura oficial. Revista do Patrimônio Histórico e Artístico Nacional, Rio de Janeiro, v. 22, p. 44-47, 1987.

MICELI, Sergio (org.). Estado e cultura no Brasil. São Paulo: Difel, 1984.

MOTTA, Edson; SALGADO, Maria Luiza Guimarães. O papel: problemas de conservação e restauração. Petrópolis: Museu de Armas Ferreira da Cunha (MAFC), 1971.

PARENT, Michel. O futuro do patrimônio arquitetônico. Revista do Patrimônio Histórico e Artístico Nacional, Rio de Janeiro, v. 19, p.112-123, 1984.

RICOEUR, Paul. A memória, a bistória, o esquecimento. Campinas: Editora da Unicamp, 2007.

RUBINO, Silvana. As fachadas da história: os antecedentes, a criação e os trabalhos do Serviço do Patrimônio Histórico e Artístico Nacional, 1937-1968. 1991. Dissertação (Mestrado) - Departamento de História, Instituto de Filosofia e Ciências Humanas, Universidade Estadual de Campinas, 1991.

SANT'ANN, Márcia. Da cidade-monumento à cidade-documento: A trajetória da norma de preservação de áreas urbanas no Brasil (1937-1990). 1995. Dissertação (Mestrado em História) Universidade Federal da Bahia, Salvador, 1995.

SEGALL, Maurício. Prefácio. In: Fotografia e documentação: o trabalbo de Herman Graeser. São Paulo: Museu Lasar Segall, 1981. p.7

TELLES, Augusto Carlos da Silva. Atlas dos Monumentos Históricos e Artísticos do Brasil. 2a ed. Rio de Janeiro: MEC; SEAC; FENAME, 1980 [1975].

THOMPSON, Analucia; PEREIRA FILHO, Hilário. Memória oral e IPHAN: Fontes, metodologia e reflexões no campo do patrimônio cultural. In: XXV Simpósio Nacional de História, 25, 2009, Fortaleza. Anais.... Fortaleza: ANPUH, 2009. CD-ROM.

THOMPSON, Analucia (org.). Entrevista com Judith Martins. Rio de Janeiro: Iphan; Daf; Copedoc, 2009. (Memórias do Patrimônio, 1).

Artigo apresentado em 20/01/2016. Aprovado em 12/07/2016. 